\title{
Palynofacies analysis, sedimentology and hydrocarbon potential of the Menilite Beds (Oligocene) in the Slovakian and Romanian Outer Carpathians
}

\author{
Anna FILIPEK ${ }^{1, *}$ \\ 1 University of Warsaw, Faculty of Geology, Żwirki i Wigury 93, 02-089 Warszawa, Poland
}

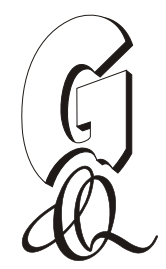

Filipek, A., 2020. Palynofacies analysis, sedimentology and hydrocarbon potential of the Menilite Beds (Oligocene) in the Slovakian and Romanian Outer Carpathians. Geological Quarterly, 64 (3): 589-610, doi: 10.7306/gq.1541

\begin{abstract}
The sedimentary organic matter (SOM) assemblages and sedimentology of the Menilite Beds from the Dukla, Grybów and Vrancea units in the Slovakian and Romanian Outer Carpathians are described. Qualitative and quantitative analyses of the SOM help ascertain depositional conditions, while the thermal maturity of the organic matter studied is estimated utilizing the Spore Colour Index and UV light excitation techniques. The sedimentary organic particles were grouped into ten SOM categories: marine palynomorphs (dinoflagellate cysts), sporomorphs (saccate and non-saccate, pollen and spores), freshwater algae (Botryococcus sp., and other freshwater microplankton), phytoclasts (cuticles, translucent wood, opaque wood), resin and amorphous organic matter (AOM). All samples are dominated by AOM. The presence of Botryococcus sp., Pediastrum sp., Pterospermella sp. and Campenia sp., in some samples points to deposition under hyposaline conditions. It is interpreted that the freshwater influx induced water column stratification in the basin, leading to the development of dysoxic to anoxic bottom-water conditions that enhanced the preservation of AOM. Kerogen analysis in UV light and evaluation using the Spore Colour Index demonstrated different thermal maturation patterns from the Slovakian (post-mature) and Romanian (immature) sections. Integrated palynofacies analysis (notably, the presence of freshwater algae) and sedimentological observations (e.g., hummocky cross-stratification) lead to the conclusion that the deposition of the Menilite Beds in the Vrancea Unit (Romania) was relatively proximal to the shoreline, above storm wave base, whereas the Slovakian units (Dukla and Grybów) were deposited in a more distal setting.
\end{abstract}

Key words: Menilite Beds, palynofacies, UV fluorescence, thermal maturity, Carpathians.

\section{INTRODUCTION}

Organic-rich sediments deposited in the Paratethys Ocean during the Oligocene have long been considered to be potential hydrocarbon source rocks (Zuber, 1918; Szajnocha, 1920; De Cizancourt, 1931; Gucik, 1980; Ziegler and Roure, 1999). The Menilite Beds are an example of these deposits, in which total organic carbon (TOC) can exceed 20\% (Köster et al., 1998; Kosakowski et al., 2009, 2018). Consequently, this stratigraphic unit has been investigated primarly for its geochemical properties and potential for hydrocarbon generation (Koltun, 1992 Köster et al., 1998; Kotarba et al., 2007; Belayouni et al., 2009; Kosakowski et al., 2009, 2018; Sachsenhofer et al., 2015; Wendorff et al., 2017) over many years, a particularly relevant topic given the numerous controversies regarding the depositional setting of the Menilite Beds (Kotlarczyk et al. 2006; Jankowski, 2015; Dziadzio et al., 2016). However, existing studies rarely use data from sedimentary organic matter (SOM) analyses in their environmental interpretations, relying instead on palynomorph assemblages (Olaru, 1970; Ţabără, 2010, 2017; T Tabără et al., 2015).

*E-mail: anna_filipek@student.uw.edu.pl

Received: August 2, 2019; accepted: February 19, 2020; first published online: June 26, 20202
Biostratigraphic studies based on calcareous nanoplankton (Belayouni et al., 2009; Garecka, 2012), foraminifers (Olszewska, 1982, 1985), dinoflagellate cysts (Tabără, 2010, 2017; Tabără et al., 2015), and ichthyofauna (Kotlarczyk et al., 2006) suggest that the Menilite Beds of the Outer Carpathians were largely deposited in the Rupelian (Early Oligocene). However, in the marginal parts of the basin, deposition continued until the Late Oligocene. In some places, deposition extended into the late Egerian-earliest Aquitanian (Miocene, NN1 Calcareous Nannoplankton Zone; Andreyeva-Grigorovich and Gruzman, 1994; Andreyeva-Grigorovich et al., 1997; Garecka, 2012; e.g., the Skole Unit). The development and deposition of Menilite-type facies (organic-rich, fine-grained Oligocene strata) across the entire Outer Carpathians (Czech Republic, Poland, Slovakia, Ukraine, and Romania) was initially driven by progressive extension in the Early Oligocene. Concurrent tectonic motion in the Paratethys region caused the isolation of the basin from the open ocean. Therefore, the restriction of saline oceanic circulation and considerable freshwater influx into the basin (Baldi, 1980) spurred water column stratification (Bojanowski et al., 2018) and the periodic development of dysoxic conditions at the sediment-water interface (Kotlarczyk and Uchman, 2012). However, Miclăuş et al. (2009) suggested that anoxic conditions might have also been favoured by increased biological productivity caused by the isolation of the Parathetys, global climate changes, or relative sea-level fluctuations. Oxygen-deficient conditions, combined with relatively 


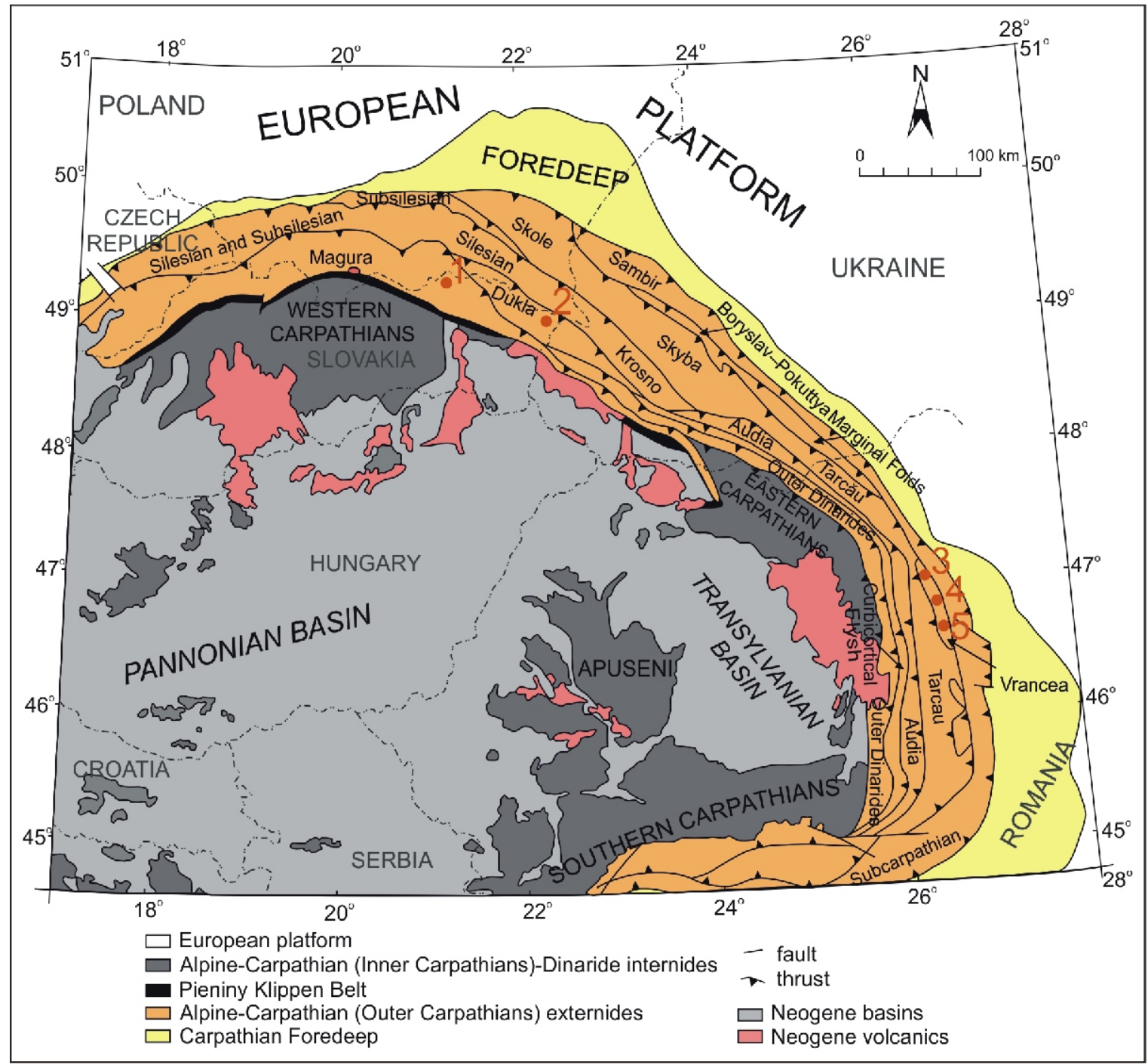

Fig. 1. Schematic map of the Alpine-Carpathian-Dinaride domain, with location of the sections studied indicated (after Kováč et al., 2007)

Slovakia: 1 - Smilno, 2 - Dara Prislop; Romania: 3 - Agapia, 4 - Piatra Neamt, 5 - Nechit

stable sedimentation, drove the deposition of organic-rich, fine-grained sediments throughout the entire basin(s), leading to a high degree of facies unification (Jankowski, 2004; Kotlarczyk and Uchman, 2012). In the geological record, the presence of anoxic events is often reflected in the enhanced preservation of SOM. A qualitative and quantitative analysis of SOM may allow for the determination of sedimentary conditions and fluctuations within the anoxic event interval across isochronous horizons and within vertical successions of macroscopically identical rocks (Pilskaln, 1991). Palynofacies analysis has the potential to reveal hitherto hidden aspects of the depositional setting and changes within the Menilite Basin.

Palynofacies analysis is based on the optical microscopy of organic matter released from the mineral phases of the rock (Combaz, 1964). This method, based on the diversity of observed organic matter, allows for the determination of the petroleum potential (by estimation of kerogen type) of the sedimentary rocks and the reconstruction of their depositional environ- ments (Tyson, 1995; Batten, 1996). Organic sedimentary particles visible under a transmitted light microscope may show a large diversity of colours, morphologies, opacities, and recognisable structures (Tyson, 1995), which is why both quantitative and qualitative palynofacies analysis are useful in reconstructing depositional settings.

This study focuses on Menilite Beds outcrops currently separated by great distances ( $600 \mathrm{~km})$ and located within different tectonic units (Fig. 1). Palynofacies and sedimentological analysis should allow for the verification of (1) sedimentary conditions within the Oligocene Carpathian basin(s) in potentially distant depositional zones and (2) organic matter distributions as reflected in the present tectonic pattern.

The aims of the present study include: (1) a palynofacies characterisation of the Menilite Beds within the Vrancea Unit (Romania) and the Smilno and Dara Prislop units (Slovakia); (2) a determination of their respective sedimentary settings; and (3) an assessment of the hydrocarbon potential of the Menilite Beds. 


\section{GEOLOGICAL SETTING}

The study area is located within the Outer Carpathians, alternatively referred to as the Flysch Carpathians (e.g., Kováč et al., 2007; Jankowski et al., 2012). The Carpathians are the eastern prolongation of the Alpine arc and were formed after the closure of the Tethys Ocean during the Cretaceous to the Miocene, as a consequence of the collision of a series of microplates with the European Platform (Froitzheim et al., 2008). According to the majority of conceptual models, this process may have terminated with the subduction of the European Platform margin under a group of microplates, coincident with the complete closure of the Tethys Ocean. This, in turn, resulted in the deformation and imbrication of strata accumulated within the so-called Outer Carpathian Basin (Jankowski, 2015; Olszewska and Szydło, 2017), the Carpathian Foreland Basin (e.g., Grasu et al., 1999; Puglisi et al., 2006; Miclăuş et al. 2009), or the Outer Carpathian Ocean (Golonka et al., 2006) and their partial overthrusting onto the platform (Mahel' and Buday, 1968; Książkiewicz, 1972; Mahel', 1974). Traditionally, in its western extent the Carpathian Orogen is subdivided into the Inner Carpathians and the Outer Carpathians (see Mahel' and Buday, 1968; Książkiewicz, 1972).

In Romania, the Outer Carpathians are referred to as the Moldavide Belt (Săndulescu, 1975, 1980). In some reports (Andrusov, 1968; Plašienka et al., 1997), the term "Central Western Carpathians" is used interchangeably with "Inner Western Carpathians". The boundary between the Inner and Outer Carpathians is traditionally interpreted to occur along the Pieniny Klippen Belt, a narrow structure presently interpreted in two ways: (1) as a Early/Middle Miocene suture between the European foreland and the Alcapa Block of the Inner Carpathians (Birkenmajer, 1986; Csontos and Nagymarosy, 1998), or (2) as a tectonic melange zone (Jankowski, 2015) developed along a strike-slip fault (Birkenmajer, 1977; Jurewicz, 2005) and characterized by the presence of both older (Triassic, Jurassic, Cretaceous) and younger (Paleogene) strata. In the marginal Inner and the southern part of the Outer Carpathians, Oligocene sediments were deposited in basins during the extensional phase (Central Carpathian Paleogene Basin - Janočko and Jacko, 1998; Soták, 1998; East Carpathian Paleogene Basin - Jarmołowicz-Szulc and Jankowski, 2011). In the Romanian portion of the Carpathians, Oligocene sediments were deposited in the hinterland of the Outer Carpathians or in the Moldavides. Traditionally, the following units are distinguished in the Slovakian and Polish segments of the Outer Carpathians: from south to north, the Magura Unit, the Dukla Unit, the Silesian Unit, a narrow belt of the Węglówka Unit, and the Skole Unit. Some researchers (see Kotlarczyk, 1988; Jankowski et al., 2004) also distinguish the Boryslav-Pokuttya Unit in the vicinity of Przemyśl.

The Romanian Carpathians are also subdivided into two regions: an inner one, composed of crystalline basement nappes and Mesozoic sedimentary rocks, and an outer one, primarily composed of Cretaceous and Paleogene flysch deposits (Săndulescu, 1975, 1980; Balla, 1986; Badescu, 1997). The innermost tectonic units (i.e., the Macla and Audia nappes) and the outermost units (the Tarcău, Vrancea and Subcarpathian nappes) constitute the Moldavide Nappe Complex (Săndulescu, 1975; Badescu, 1998; Fig. 1).

According to many studies, deposition within the Carpathians took place in a series of basins or sub-basins that correspond to the present-day units of the Outer Carpathians (Książkiewicz, 1972; Golonka and Krobicki, 2004; Ślączka et al., 2006, 2012; Oszczypko-Clowes et al., 2015). The Skole, Sub-Silesian, Silesian, Dukla, and Magura sub-basins and their eastern prolongation formed part of the rifted European margin (Oszczypko and Oszczypko-Clowes, 2003; Golonka et al., 2006). Adjacent basins were locally separated by ridges: for instance, the Silesian ridge separated the Silesian and Magura basins (e.g., Golonka et al., 2006). According to Birkemajer (1986) and Golonka et al. (2006), it is envisioned that the Silesian and Magura basins were underlain by oceanic basement. Traditionally, these basins have been interpreted as primarily filled with deep-water, mostly tubiditic deposits (e.g., Kotlarczyk and Uchman, 2012). However, some authors have recently suggested that deposition in these areas took place in a single basin, subject to multi-stage rebuilding as a result of changes in the tectonic regime (Jankowski, 2004). In this case, the formation of the Carpathian basins was driven mainly by decomposition of the East European Platform margin. Contractional stages pinpoint the formation of a foreland basin (Jankowski and Wysocka, 2019). Jankowski (2007, 2015) and Jankowski and Wysocka (2019) have additionally distinguished an extensional stage, during which sedimentation took place in half-graben structures. The process of basin closure and sedimentation cessation was diachronous, progressing from west to east; in Romania, this process extended into the Pliocene (e.g., Royden and Baldi, 1988; Linzer et al., 1998; Golonka et al., 2006).

\section{MENILITE BEDS}

The Menilite Beds (the name is derived from a variety of opal, known as menilite; Glocker, 1843) occur in almost all tectonic elements of the Western and Romanian Carpathians (Murgeanu et al., 1970; Lexa et al., 2000; Jankowski et al., 2004, 2007, 2012; Wagner, 2008). The unit is also referred to as the Menilite Formation, Amphisyla, the Disodilic Beds (Cordier, 1808, derived from disodil, a variety of menilite), and the Meletta, Czeczwin, and Smilno beds (Glocker, 1843; Jankowski et al., 2004, 2007, 2012). In the western part of the Romanian Carpathians, the Menilite Beds are divided into two units: (1) the Menilite Beds (lower), which mainly consists of cherts and shales, is separated by the Bituminous Marl from (2) the shale unit (upper) with cherts and sandstones, here referred to as the Disodilic Beds (upper; e.g., Jankowski et al., 2012; Tabără, 2017; Fig. 2). In the Slovakian Carpathians, the Menilite Beds are divided into three subunits: (1) the Cherts, (2) the Lower Menilite Beds, and (3) the Upper Menilite Beds (Stránik and Hanzlikowá, 1963). The Menilite Beds are variable in thickness, which is largely controlled by the development of sandstone units (e.g., Gucik and Wójcik, 1982; Gucik, 1987; Kotlarczyk and Leśniak, 1990; Kotlarczyk et al., 2006). Jarmołowicz-Szulc and Jankowski (2011) interpreted the occurrence of different lithologies (i.e., conglomerates, sandstones, diatomites, marls, carbonates, and different types of shale) as associated with deposition in morphologically diverse basin(s).

The deposition of the Menilite Beds initiated in the early Oligocene in an isolated, marginal part of the Paratethys. The basin was characterized by fluctuating salinity and restricted circulation (Baldi, 1980; Popov et al., 2010). The Menilite Beds are dominated by organic-rich, fine-grained strata deposited under anoxic conditions (e.g., Pauča, 1936; Vetö, 1987; Sachsenhofer et al., 2015). The basal boundary of the Menilite Beds is considered to be isochronous (Olszewska, 1985). In contrast, their upper boundary is diachronous (Garecka, 2008, 2012). The Menilite Beds are progressively overlain from the south by the Krosno Beds. In the marginal portions of the Outer Carpathian Basin(s), sedimentary breccias, such as the Slon Beds, the Gura Soimului Beds, and the Vorotyshcha Beds, overlie the Menilite Beds (Fig. 2; Grasu et al., 1988; Jankowski et al., 2012). 


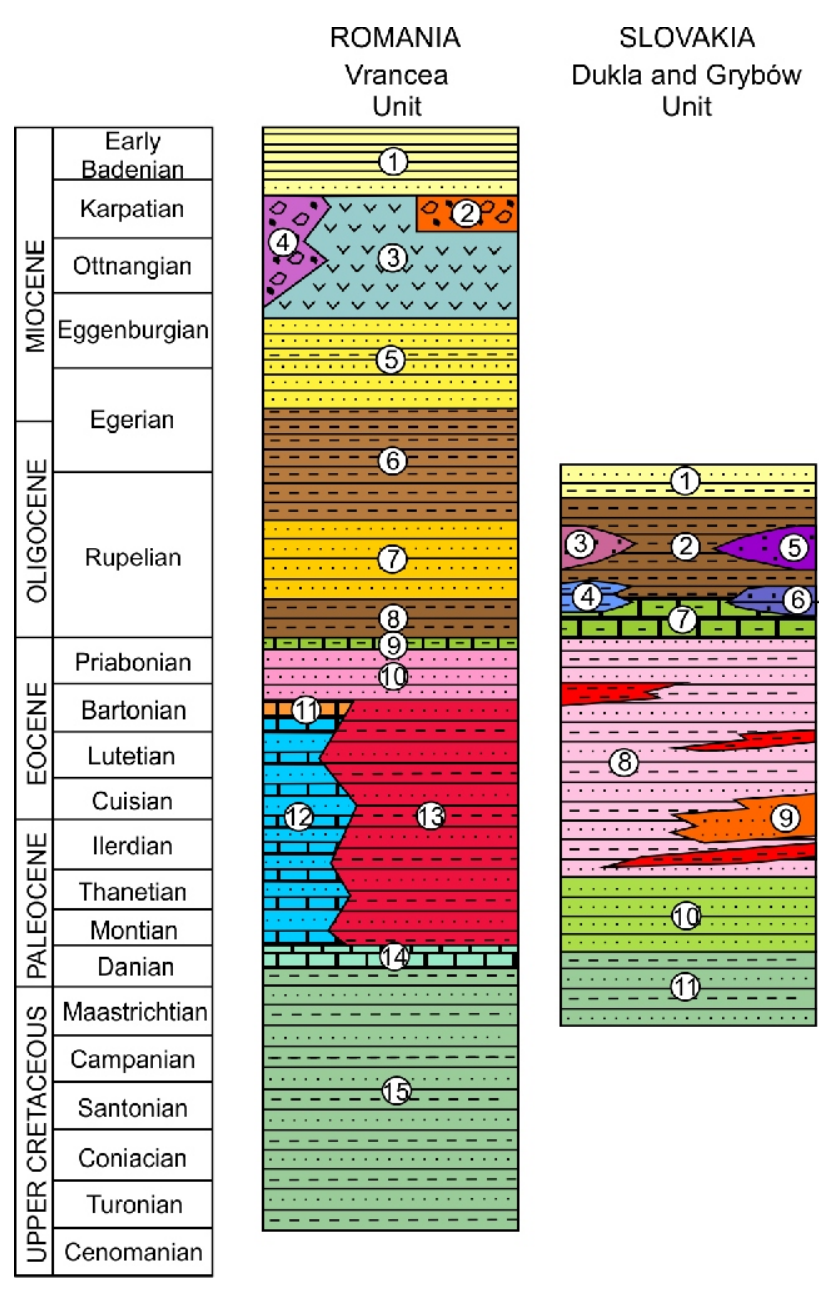

Fig. 2. Correlation of regional lithostratigraphic units (based on Jankowski et al., 2012) with the exposures studied indicated

Units from which samples were collected are underlined; Romania, Vrancea Unit: 1 - Doftana Beds, 2 - Brebu Conglomerate, 3 - Salt Beds, 4 - Slon Beds, 5 - Gypsum Beds (Gura Soimului Beds, Gura Misina Beds), 6 - Upper Dysodilic Shale, 7 - Kliva Sandstone, 8 Lower Dysodilic Shale, Bituminous Marl, Menilite Beds, 9 Globigerina Marl, Lucăceşti Sandstone, 10 - Bisericani Beds, 11 Doamna Beds, 12 - Jgheabu Marl, 13 - Greşu Beds, 14 - Piatra Uscata Beds, Caşin Beds, 15 - Lepşa Beds; Slovakia, Dukla and

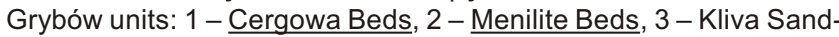
stone, 4 - Cergowa Sandstone, 5 - Papin Beds, 6-Mszanka Beds, 7 - Globigerina Marl, 8 - Submenilite Beds, 9 - Bukovec Sandstone, 10 - Cisna Sandstone, 11 - Łupków Beds

Thin layers of coccolithic limestone, presumably related to phytoplankton blooms, are found in the Menilite Beds (Uhlig, 1882; Nowak, 1965; Haczewski, 1989; Ciurej and Haczewski, 2016). These layers - the Tylawa, Wujskie, and Jasło limestones - are considered to be isochronous (Jucha and Kotlarczyk, 1961; Koszarski and Żytko, 1961; Jucha, 1969; Kotlarczyk et al., 2006). In the lower part of the Menilite Beds succession, regional tuff horizons (Sikora et al., 1959; Koszarski and Wieser, 1960) and diatomites (the Futoma Diatomite) are recognized (Krzyżanowski, 1962; Kotlarczyk, 1988; Kotlarczyk and Leśniak, 1990).

Numerous lithostratigraphic equivalents of the Menilite Beds have been distinguished, which are referred to as the "Menilite facies" due to their common features (Oligocene organic-rich, primarily fine-grained strata; Jarmołowicz-Szulc and
Jankowski, 2011). The Menilite Beds are present within the successions of the Central Carpathian Paleogene Basin (Poland, Slovakia, and the Czech Republic), the Buda-type Paleogene (Croatia, Slovenia and Hungary), the Transylvanian Basin (Romania), and the Black Sea region (Ukraine and Russia; Puglisi et al., 2006; Jarmołowicz-Szulc and Jankowski, 2011; Filipek et al., 2017; Mayer et al., 2018). The Menilite Beds are stratigraphically equivalent to a portion of the fine-grained source rocks from the eastern Paratethys called the Maikop Group, which was deposited in similar, brackish-water conditions during the "Solenovian Event" (Voronina and Popov, 1984; Popov et al., 1993; Popov and Studencka, 2015). In particular, marlstones with different regional nomenclature (the Dynów Marl, the Ostracoda Beds and the Romanian Bituminous Marl) are considered to be a Paratethys-wide marker horizon (Mayer et al., 2018). Uniform, shallow-water faunas of small bivalves, with the notable presence of Solenovian-type endemic genera, locally together with various faunal groups (e.g., freshwater calcareous nannofossils, marine fish), have been identified in these marlstones in Poland, Ukraine, the Czech Republic, Kazakhstan, Georgia and Romania (Kazakhashvili, 1984; Voronina and Popov, 1984; Rusu, 1999; Popov and Studencka, 2015; Studencka et al., 2016).

\section{HYDROCARBON POTENTIAL OF THE MENILITE BEDS}

The Outer Carpathians are one of the oldest petroleum-producing regions in the world: the first oil exploration in this region was documented in 1853 (Karnkowski, 1999). Petroleum accumulations have been identified in almost all sandy lithostratigraphic members (the Istebna, Hieroglyphic and Krosno Beds; Fig. 2) and in the Paleozoic-Mesozoic basement of the Outer Carpathians (Kotarba and Koltun, 2006; Więcław et al., 2011).

The bituminous Menilite Beds are considered to be the one of the source units in the Carpathian region (see Zuber, 1918; lonescu, 1994; Dicea, 1995; Kotarba and Koltun, 2006; Stefanescu et al., 2006; Belayouni et al., 2009; Kosakowski, 2013). The high hydrocarbon potential of the Menilite Beds is interpreted and deduced based on its high TOC values and kerogen type. In some localities, TOC exceeds $20 \%$ (Köster et al., 1998; Kosakowski et al., 2009, 2018; Sachsenhofer et al., 2015; Jirman et al., 2018; Rauball et al., 2019). The kerogen content of the Menilite Beds consists mainly of oil-prone, low-sulphur Type-II kerogen, with the occasional occurrence of Type-III kerogen (Curtis et al., 2004; Lewan et al., 2006; Kosakowski et al., 2009; Rauball et al., 2019). In the Menilite Beds, variability in kerogen type reflects a combination of the input of different sources of organic matter, together with variable environmental conditions and bathymetry (Kotarba and Koltun, 2006). Within the Outer Carpathians, the eastern part of the Silesian Unit and the Ukrainian region are characterized by the greatest hydrocarbon potential, primarily due to the dominance of oil-prone Type-II kerogen (Kotarba and Koltun, 2006). The Menilite Beds reached a spectrum of distinct thermal maturation levels, primarily driven by variations in organic matter type, burial history, and geothermal gradient (e.g., Stefanescu et al., 2006).

Geochemical analyses of the Menilite Beds in several outcrops in the Polish, Ukrainian and Romania Carpathians indicate that the stratigraphic unit is thermally immature to marginally mature, reaching into the early stages of the oil window (Curtis et al., 2004; Anastasiu, 2016; Wendorff et al., 2017; Kosakowski et al., 2018; Rauball et al., 2019). In the Polish and Ukrainian Carpathians, thermal maturity of the Menilite Beds increases from the outer to the inner tectonic units, from imma- 
Table 1

GPS coordinates for the investigated exposures (source: ArcGIS Basemap)

\begin{tabular}{|c|c|c|c|}
\hline Locality & Sample & \multicolumn{2}{|c|}{ GPS coordinates } \\
\hline Dara Prislop & $\begin{array}{c}\text { DP } 10, \text { DP 9B, DP 9A, DP 8B, DP 8A, } \\
\text { DP 7, DP 6, DP 5C, DP 5B, DP 5A, } \\
\text { DP 4B, DP 4A, DP 3B, DP 3A, DP 2, } \\
\text { DP } 1 A\end{array}$ & $49^{\circ} 2^{\prime} 50.644 " \mathrm{~N}$ & $22^{\circ} 17^{\prime} 25.598^{\prime \prime} \mathrm{E}$ \\
\hline \multirow{5}{*}{ Smilno } & S 2 & $49^{\circ} 21^{\prime} 22.026 " \mathrm{~N}$ & $21^{\circ} 25^{\prime} 45.778 " \mathrm{E}$ \\
\hline & S 12 & $49^{\circ} 21^{\prime} 22.026 " \mathrm{~N}$ & $21^{\circ} 25^{\prime} 45.778 " \mathrm{E}$ \\
\hline & S 16 & $49^{\circ} 21^{\prime} 22.026 " \mathrm{~N}$ & $21^{\circ} 25^{\prime} 45.778 " \mathrm{E}$ \\
\hline & S 24 & $49^{\circ} 21^{\prime} 22.421^{\prime \prime} \mathrm{N}$ & $21^{\circ} 25^{\prime} 45.500 " \mathrm{E}$ \\
\hline & S 30 & $49^{\circ} 21^{\prime} 22.421 " \mathrm{~N}$ & $21^{\circ} 25^{\prime} 45.500 " \mathrm{E}$ \\
\hline \multirow{13}{*}{ Nechit } & N 1008b, N 1008a & $46^{\circ} 45^{\prime} 55.166^{\prime \prime N} \mathrm{~N}$ & $26^{\circ} 26^{\prime} 19.824 " \mathrm{E}$ \\
\hline & $1003 a$ & $46^{\circ} 46^{\prime} 15.899^{\prime \prime N} \mathrm{~N}$ & $26^{\circ} 25^{\prime} 37.715 " \mathrm{E}$ \\
\hline & 1001 & $46^{\circ} 46^{\prime} 14.949 " \mathrm{~N}$ & $26^{\circ} 25^{\prime} 31.904 " \mathrm{E}$ \\
\hline & 1000 & $46^{\circ} 46^{\prime} 15.107^{\prime \prime N} \mathrm{~N}$ & $26^{\circ} 25^{\prime} 27.847^{\prime \prime E}$ \\
\hline & $993 b$ & $46^{\circ} 46^{\prime} 21.166^{\prime \prime N} \mathrm{~N}$ & $26^{\circ} 25^{\prime} 12.933^{\prime \prime E}$ \\
\hline & 991 & $46^{\circ} 46^{\prime} 20.298^{\prime \prime N} \mathrm{~N}$ & $26^{\circ} 25^{\prime} 8.461^{\prime \prime E}$ \\
\hline & 977 & $46^{\circ} 46^{\prime} 16.468^{\prime \prime N} \mathrm{~N}$ & $26^{\circ} 24^{\prime} 11.765 " \mathrm{E}$ \\
\hline & 971 & $46^{\circ} 46^{\prime} 14.246^{\prime \prime N} \mathrm{~N}$ & $26^{\circ} 23^{\prime} 58.661 " \mathrm{E}$ \\
\hline & 962 & $46^{\circ} 45^{\prime} 53.777^{\prime \prime N} \mathrm{~N}$ & $26^{\circ} 23^{\prime} 4.056^{\prime \prime E}$ \\
\hline & 961 & $46^{\circ} 45^{\prime} 53.042^{\prime \prime} \mathrm{N}$ & $26^{\circ} 23^{\prime} 1.766^{\prime \prime E}$ \\
\hline & 960 & $46^{\circ} 45^{\prime} 52.801 " \mathrm{~N}$ & $26^{\circ} 23^{\prime} 1.277^{\prime \prime E}$ \\
\hline & 952 & $46^{\circ} 45^{\prime} 53.064^{\prime \prime N} \mathrm{~N}$ & $26^{\circ} 22^{\prime} 50.754 " \mathrm{E}$ \\
\hline & 949 & $46^{\circ} 45^{\prime} 51.595 " \mathrm{~N}$ & $26^{\circ} 22^{\prime} 46.762 " \mathrm{E}$ \\
\hline \multirow{4}{*}{ Piatra Neamt } & PN KG & $46^{\circ} 56^{\prime} 27.840^{\prime \prime} \mathrm{N}$ & $26^{\circ} 22^{\prime} 10.320^{\prime \prime E}$ \\
\hline & PN SPK & $46^{\circ} 56^{\prime} 13.200^{\prime \prime} \mathrm{N}$ & $26^{\circ} 22^{\prime} 10.320^{\prime \prime E}$ \\
\hline & PN PM & $46^{\circ} 56^{\prime} 5.220 " \mathrm{~N}$ & $26^{\circ} 22^{\prime} 4.320^{\prime \prime} \mathrm{E}$ \\
\hline & PN PK & $46^{\circ} 56^{\prime} 17.940 " \mathrm{~N}$ & $26^{\circ} 22^{\prime} 7.860^{\prime \prime} \mathrm{E}$ \\
\hline \multirow{3}{*}{ Agapia } & A 1040b, A 1040a & $47^{\circ} 9^{\prime} 43.715 " \mathrm{~N}$ & $26^{\circ} 13^{\prime} 50.696 " \mathrm{E}$ \\
\hline & A 1041 & $47^{\circ} 9^{\prime} 44.525^{\prime \prime} \mathrm{N}$ & $26^{\circ} 13^{\prime} 50.308^{\prime \prime E}$ \\
\hline & A 1042j, 1042c & $47^{\circ} 9^{\prime} 46.019 " \mathrm{~N}$ & $26^{\circ} 13^{\prime} 54.415^{\prime \prime E}$ \\
\hline
\end{tabular}

ture in the Skole and Boryslav-Pokuttya units to overmature in the southern parts of the Silesian and Dukla units (Kotarba et al., 2007; Kosakowski et al., 2018). A similar relationship between thermal maturity and location within the orogen was also noticed in Romania (Vrancea and Tarcău units) by Wendorff et al. (2017). However, at some localities in Ukraine (the Boryslav-Pokuttya Unit and locally the Skiba Unit), where the unit was buried to between 3 and $6 \mathrm{~km}$ depth, the Menilite Beds are in the oil or gas window (Koltun, 1992; Kosakowski et al. 2018). The organic geochemical compounds of oils, and in particular the presence of oleanane, at these localities suggest that they were generated from the Menilite Beds (Kotarba and Koltun, 2006; Więcław et al., 2012) from an early stage to the peak of the oil window.

The presence of sandstone and conglomerate lithosomes in the Menilite Beds (e.g., the Kliva, Magdalena and Cergowa Sandstones, and the Maly Vyžen Beds; Jankowski et al., 2012) is important, as these coarse-grained siliciclastic strata serve as potential hydrocarbon migration routes or reservoir rocks. Coarse-grained deposits of Oligocene age have good reservoir potential in both shallow and deep structures of the Outer Carpathians (Dziadzio et al., 2006). In some areas, the Menilite Beds may be source rocks as well as reservoir rocks.

\section{MATERIAL}

In the present study, samples were collected from three geological units: the Dukla and Grybów units (Slovakia), and the Vrancea Unit (Romania; Fig. 1 and Table 1). In total, 42 samples from the Menilite Beds were collected from the following exposures: Smilno (Slovakia; 5 samples), Dara Prislop (Slovakia; 16 samples), Piatra Neamt (Romania; 4 samples), the Nechit River (Romania; 14 samples), and Agapia (Romania; 3 samples from the Menilite Beds and 2 samples from the Slon Beds (equivalent of the Vorotyshcha Beds; Fig. 1). It can be assumed, based on lithostratigraphic studies (Kotlarczyk et al., 2006; Jankowski et al., 2012), that the Menilite Beds of Romania (Nechit, Bituminous Marl) and Slovakia (Dara Prislop, Cergowa Beds) were deposited at approximately the same time. To evaluate differences in organic matter distribution between the various parts of the sedimentary basin, the samples were collected at locations originally distant from each other during the deposition of the Menilite Beds. Furthermore, these localities are located in different tectonic units at present, allowing for an assessment of post-depositional variability in their development (e.g., thermal maturity differentiation). 


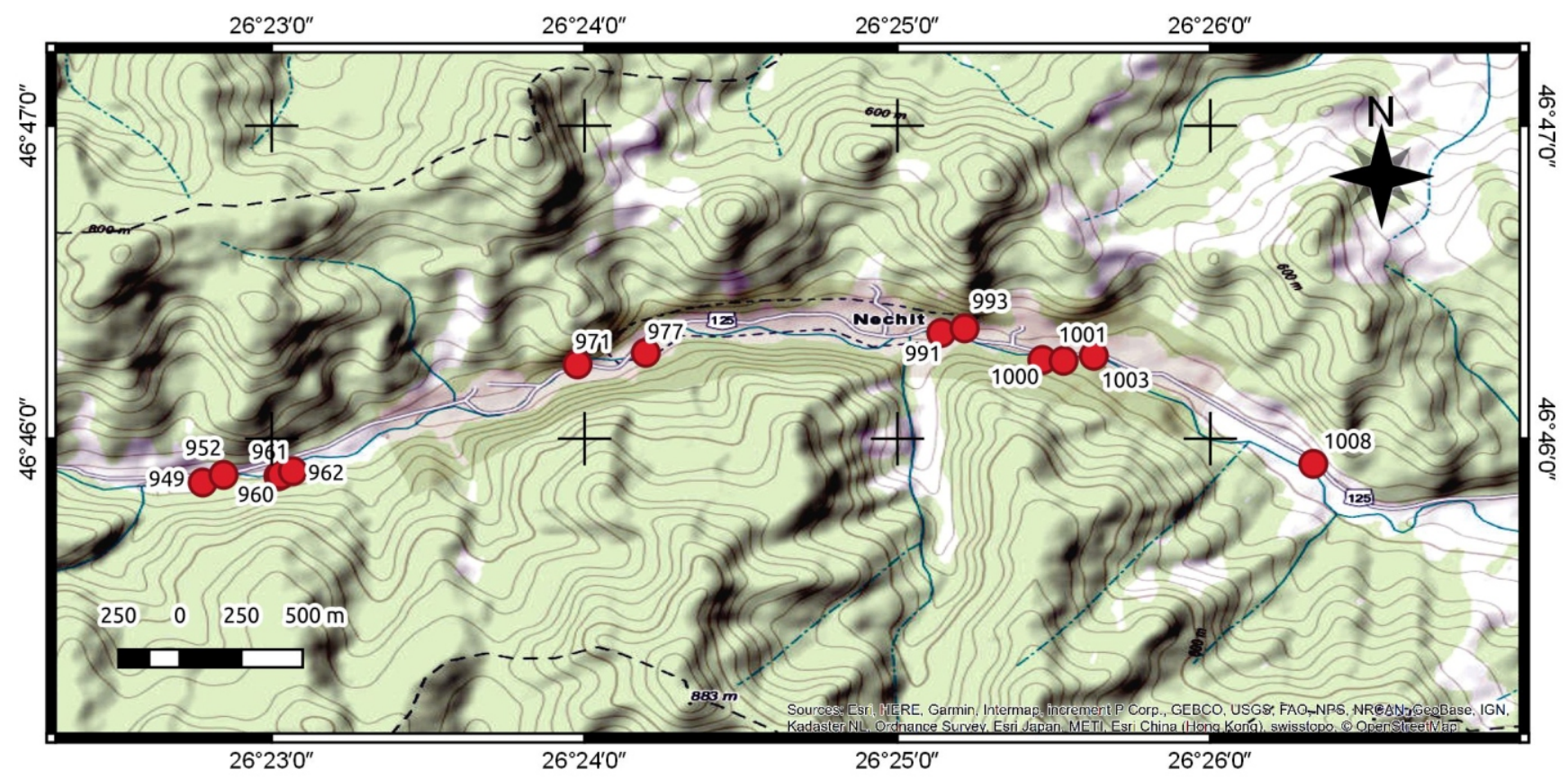

Fig. 3. Topographic map of the Nechit River area (Vrancea Unit, Romania), with sampling sites marked

The number and distribution of samples from each section was dependent on the accessibility and type of exposure. In tectonically undisturbed sections of considerable thickness (Dara Prislop, Smilno, Piatra Neamt, and Agapia), samples were collected within the stratigraphic order of the section. At the Nechit River site, owing to regional folding and the partly inaccessible nature of the Menilite Beds, the samples were collected from exposures located along the stream (Fig. 3). Samples were collected from various lithologies (mainly shales) at each of these localities (Figs. 4 and 5).

\section{METHODS}

All samples collected were processed following modified palynological techniques used at the laboratory of the Faculty of Geology, University of Warsaw. 40.23-43.00 grams of crushed rocks were treated with $37 \%$ hydrochloric acid to remove carbonates. Different times of $\mathrm{HCl}$ were used according to the carbonate content of individual samples. At least one hour of $\mathrm{HCl}$ treatment was enough for shales and mudstones. In case of samples of marl and limestone, small amounts of $\mathrm{HCl}$ are successively added until acceleration of the reaction ceases. After that samples were washed with $\mathrm{H}_{2} \mathrm{O}$, which is removed during decanting. Then $70 \%$ hydrofluoric acid was used to remove silica and silicates. Samples with HF were left for one week. The organic residuum was sieved through a $15 \mu \mathrm{m}$ mesh sieve. In order to concentrate palynomorphs, a heavy liquid separation was used $\left(\mathrm{ZnCl}_{2}\right.$; density $\left.2.0 \mathrm{~g} / \mathrm{cm}^{3}\right)$ and the residuum was sieved once again through a $15 \mu \mathrm{m}$ mesh sieve. Slides were made for each sample, using UV-cured glue as the mounting medium. Microphotographs were taken in transmitted and UV light using a Nikon Eclipse E-600 microscope equipped with a digital camera.

In the present study, at least 300 SOM particles were counted, and statistical analyses were conducted using various organic components of the SOM (Tyson, 1995). The abundant structureless AOM was studied under UV light to determine its primary components and the degree of subsequent reworking (e.g., Van Gijzel, 1961). The SOM recognized in this study is grouped into ten categories (sensu Combaz, 1964), shown in Table 2. The maturity of the Menilite Beds was also evaluated using the Spore Colour Index Chart and this was used for the first time in the Slovakian area (Fischer et al., 1980).

\section{RESULTS}

LITHOLOGY AND SEDIMENTOLOGICAL FEATURES OF THE SECTIONS STUDIED

\section{SMILNO}

The section studied in Smilno is located in the Grybów Unit (Slovakia). In this exposed section the Menilite Beds are dominated by fine-grained deposits (laminated siltstones, shales), which are in places interbedded with sandstone layers characterized by sedimentary structures including horizontal lamination, lenticular bedding, flaser bedding, ripple cross-lamination, sole marks (Fig. 4E) and deformation structures. The shales are mainly black and locally contain traces of oil. Samples were collected from the shales.

\section{DARA PRISLOP}

In the Dara Prislop section (Slovakia), the Cergowa Beds sandstones were observed. They are represented by several repetitive sequences of clastic rocks (mostly characterized by a fining-upwards sequence; Fig. 4B). Most packages start with micaceous, fine-grained sandstones, which transition into grey sandy mudstones, ultimately capped by black siltstones/shales. Sole marks (tool marks and flute moulds), indicative of different palaeotransport directions (from $\mathrm{E}$ to $\mathrm{W}$, and from $\mathrm{N}$ to $\mathrm{S}$ ), were identified in the section (Fig. 4C). Convolution and load structures were also present in the sandstone layers (Fig. 4D). Samples for palynofacies analysis were collected from different lithologies, with the intention of recognising the diversity of SOM in various rock types. 

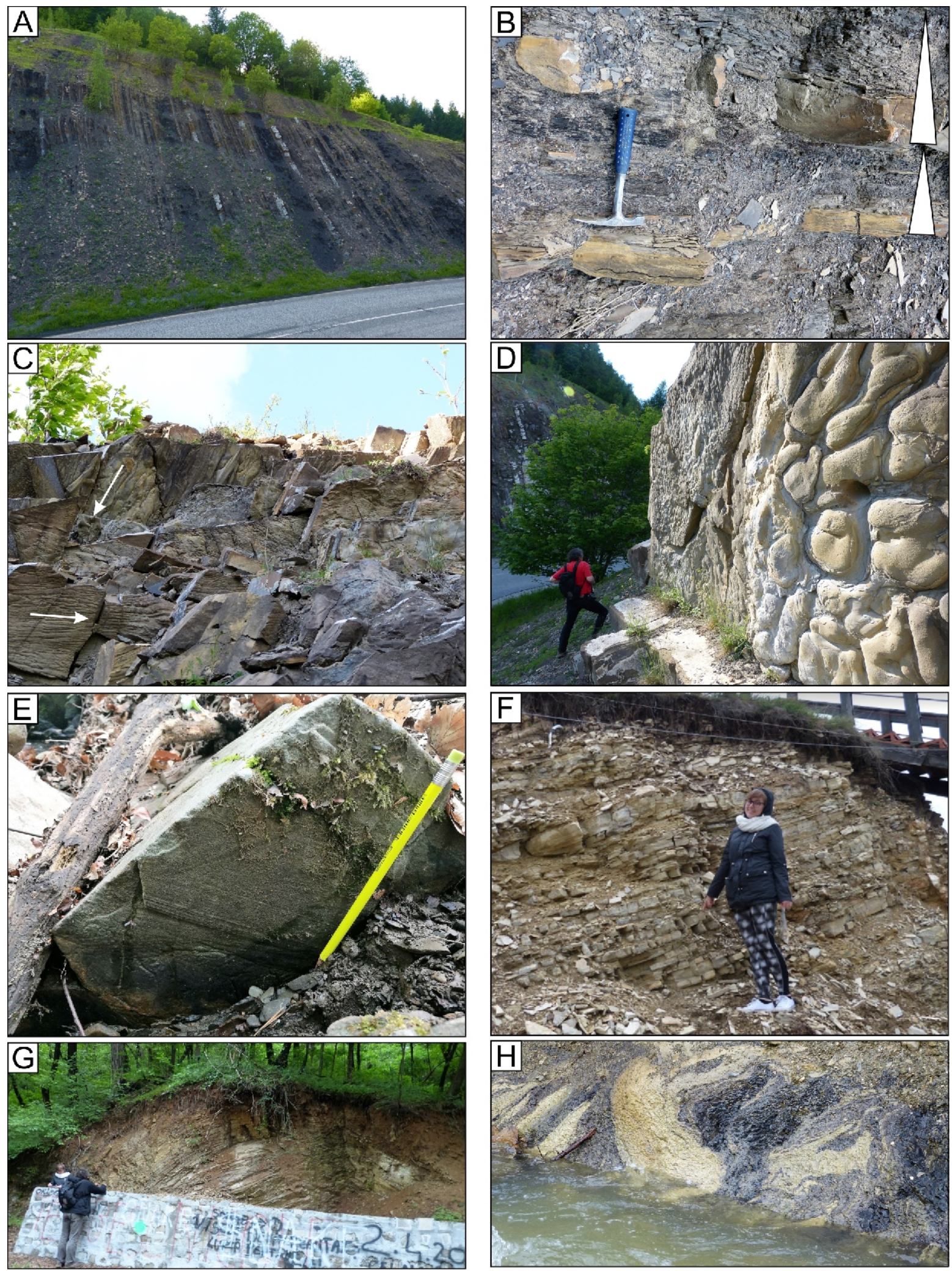

Fig. 4. Menilite Beds and Slon Beds in the Slovakian and Romanian sections

A - general overview of the exposure at Dara Prislop; B - packages represented by repeated clastic rock sequences (fine-grained sandstones through sandy mudstones passing into siltstones), Dara Prislop, triangles indicate fining-up successions; C - sole marks (Dara Prislop), arrows point in the direction of transport; D - load structures (Dara Prislop); E - sole marks (Smilno); $\mathbf{F}$ - general overview of the Bituminous Marl exposure at Piatra Neamt; $\mathbf{G}$ - general overview of the Menilite Shale exposure at Piatra Neamt; $\mathbf{H}$ - strongly deformed clasts of the Menilite Shale incorporated into a yellow matrix (Slon Beds, Agapia); photographs A-D, F-H by Anna Wysocka, photograph E by Marcin Barski 

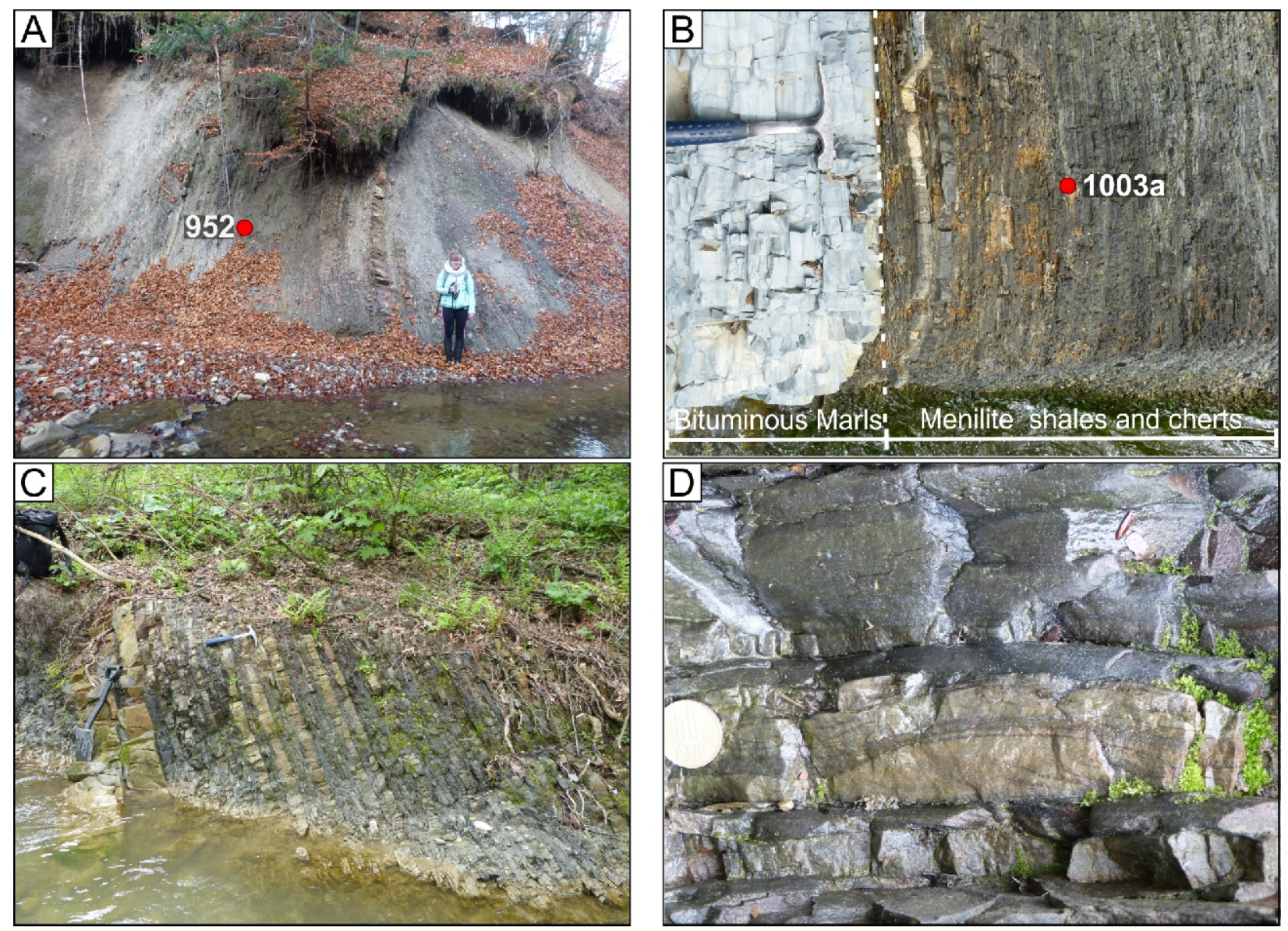

Fig. 5. Selected photographs of the Nechit River section

A - general overview of an exposure in the Nechit River section dominated by black shales and thinly-bedded cherts (red dot marks sample 952); B - boundary between the Menilite shales and cherts and the Bituminous Marl (red dot marks the location of sample 1003a); C - shale-sandstone bed packet with hummocky cross-stratification structures; D - sandstones with hummocky cross-stratification structures, sample 993b

AGAPIA

In the Agapia section (Romania), samples were collected from 2 exposures, which are $20 \mathrm{~m}$ apart. The exposures are separated by a stream, so the contact between them is not visible. In the first exposure, the Bituminous Marl was exposed in the lower part, overlain by bituminous siliceous shales with some sandstone intercalations in the upper part. At the top of the section, the proportion of thin-bedded sandstones increases. Load structures are occasionally visible in the lower parts of the sandstone beds. The Slon Beds (Oligocene-Miocene) were present in the second exposure, and are composed of sandstone-claystone breccias, primarily cemented by dark grey clays and mudstones. Menilite shale clasts have been identified within the Slon Beds ("Vorotyshcha Beds" facies). The strongly deformed clasts of Menilite shales are incorporated into a yellow matrix. Samples were collected from both the matrix and clasts to perform a comparative analysis.

PIATRA NEAMT

In the Piatra Neamt area (Romania), samples were collected from 4 exposed sections. The Bituminous Marl was present in the first (PN KG) and the second exposure (PN SPK). Marls characterized by horizontal laminations, with fish skeletons and scales, are interbedded with brown carbonate-rich shales. The third exposure (PN PM) represents mainly monotonous brown siliceous shales typical of the Menilite Beds. The last exposure (PN PK) is dominated by grey shales and thin-bedded sandstones.

NECHIT

Fieldwork in Nechit was focused on sedimentological analysis and sampling along the Nechit stream. Due to intense regional folding and the partly inaccessible nature of the Menilite Beds here it was not possisble to create a single log (Fig. 3). In exposure 949, cherts are exposed in the lower part and overlain by black and brown shales, which are interbedded with thin- and medium-bedded sandstones. In the upper part of the exposure, slumped deposits occur. The Menilite Beds, in exposures 952, 1000, 1001, 960 and 962, are represented only by brown shales. In exposures 961 and 991 siliceous bituminous brown marls (Bituminous Marls) were identified. In exposure 961, the sample was taken from the upper part of a marl package.

Exposure 971 is characterized by a reversed stratigraphic order, as shown by load structures. The lower part is dominated by dark shales, which are intercalated with locally horizontally laminated sandstone beds. In the upper part, thick-bedded massive sandstones and conglomerates with erosional boundaries occur. In one of these, chert and sandstone pebbles were identified. 
Classification of sedimentary organic matter (SOM; modified after Tyson, 1993, 1995; Roncaglia, 2004; McArthur et al., 2016)

\begin{tabular}{|c|c|c|c|c|}
\hline Group & Subgroup & Category & & Characteristics/Example \\
\hline \multirow{8}{*}{ Structured } & \multirow{5}{*}{ Palynomorphs } & $\begin{array}{l}\text { Organic-walled marine } \\
\text { phytoplankton }\end{array}$ & Dinoflagellate cysts & $\begin{array}{c}\text { Resting cysts produced by Dinoflagellata } \\
\text { sensu Williams et al. (1998) }\end{array}$ \\
\hline & & \multirow[b]{2}{*}{ Other microplankton } & Botryococcus & $\begin{array}{l}\text { Brackish-water tolerant freshwater colonial } \\
\text { green algae Botryococcus sp. }\end{array}$ \\
\hline & & & $\begin{array}{l}\text { Other } \\
\text { microplankton }\end{array}$ & $\begin{array}{c}\text { e.g., Quadriflagellate, spherical algae } \\
\text { Tasmanites sp., colonial freshwater algae } \\
\text { Pediastrum sp., prasinophyta (Pterospermella } \\
\text { sp.) and Campenia sp. (assigned to algae, but } \\
\text { with unclear taxonomic affinity, due to smooth } \\
\text { walls and lack of morphological features, i.e. } \\
\text { appendages, pores or laminated walls Tyson, } \\
\text { 1995) }\end{array}$ \\
\hline & & \multirow[b]{2}{*}{ Sporomorphs } & Saccates & $\begin{array}{c}\text { Saccate pollen (pollen grains with buoyancy } \\
\text { sacs) }\end{array}$ \\
\hline & & & $\begin{array}{l}\text { Other non-saccate } \\
\text { pollen and spores }\end{array}$ & $\begin{array}{c}\text { Megaspores and miospores, non-saccate } \\
\text { pollen; variable size, thickness } \\
\text { and ornamentation }\end{array}$ \\
\hline & \multirow{3}{*}{ Phytoclasts } & \multirow{3}{*}{ Macrophyte plant debris } & Cuticle & Leaf and plant membranous tissue \\
\hline & & & Translucent wood & Brown, biostructured wood, cortex \\
\hline & & & Opaque wood & Black, biochemically oxidised wood \\
\hline \multirow[t]{2}{*}{ Unstructured } & \multirow[t]{2}{*}{$\begin{array}{l}\text { Amorphous } \\
\text { organic matter }\end{array}$} & $\begin{array}{l}\text { Bacterially or phytoplankton } \\
\text { derived amorphous organic } \\
\text { matter; diagenetic amorphous } \\
\text { products of macrophyte tissues }\end{array}$ & AOM & $\begin{array}{l}\text { All particulate organic components which } \\
\text { appear structureless at the scale of light } \\
\text { microscopy (single particle of AOM was } \\
\text { determined as every piece of AOM in which } \\
\text { the minimum size is }>15 \mu \mathrm{m} \text { ) }\end{array}$ \\
\hline & & Higher plant secretions & $\begin{array}{l}\text { Unstructured } \\
\text { lithified resin }\end{array}$ & $\begin{array}{c}\text { Intra-/extra-cellular resins; mainly dark orange, } \\
\text { conchoidal }\end{array}$ \\
\hline
\end{tabular}

Exposures 977 and 1008 are dominated by black and brown shales, which are in places interbedded with mudstone debris-flow deposits with synsedimentary folds. Exposure 993 is dominated by sandstones with flaser bedding ripple cross-lamination or hummocky cross-stratification and black/brown shales. In Exposure 1000, a sharp contact between the cherts and shales (the lower part of the log) and the Bituminous Marls (upper part) is clearly visible.

\section{PALYNOFACIES ANALYSIS}

$$
\text { SMILNO }
$$

In Smilno (Fig. 4C), palynofacies in five samples are characterized by a very high abundance of AOM (93.2-99\% of SOM) and a relatively low abundance of opaque phytoclasts (1.0-6.1\%; Table 3 and Fig. 6C). The AOM is non-fluorescent. The minimum AOM abundance $(81.7 \%)$ is observed in one sample (S16) with the maximum abundance of opaque wood particles (18.3\%). In general, non-fluorescent, granular, and blocky fragments dominate the AOM in this exposure. Amorphous phytoclasts, characterized by having a surface $50 \%$ intact, were identified in the samples: these indicate an intermediate stage in their conversion to AOM. The prasinophytae alga Tasmanites sp., with a dark brown hue, was observed in sample S16.

DARA PRISLOP

From Dara Prislop, palynofacies in 16 samples are analysed. AOM (80.6-99.7\%) constitutes a majority of the SOM, with opaque phytoclasts as a minor component (0.3-17.8\%) (Table 3 and Fig. 6A-C). The AOM is dominated by granular, dark brown or black fragments in all samples. AOM may reach considerably larger sizes (reaching $\sim 700 \mu \mathrm{m}$ ) with more vari- able shapes relative to the samples from Smilno. The AOM is non-fluorescent. No lithological dependence was noted in this sample suite. Sample DR 4A differs from the other samples due to the presence of a cuticle content $(1.7 \%)$ characterized by dark brown colours.

$$
\text { AGAPIA }
$$

From Agapia, palynofacies in five samples were analysed. Samples collected from the Menilite Beds (A 1041 from the Bituminous Marls/Dynów Marl, A 1040a and A 1040b from the dark brown bituminous shales), are characterized by high AOM abundances $(80.5,82.4$ and $99.4 \%$, respectively). The palynological assemblages from the shale are more diverse than the organic matter in the Dynów Marl: seven SOM components occur in the shale samples, while only two are found in the Dynów Marl samples. Dinocysts in sample A 1040a are limited to Caligodinium sp. and the Middle Jurassic dinoflagellate cyst Nannoceratopsis sp., suggestive of reworking. UV light analysis revealed variable fluorescence types (brown and dark orange), indicating the presence of two AOM types in different preservational states. The darker one may be reworked. Sample A $1040 \mathrm{~b}$ is characterized by a more diverse dinoflagellate cyst assemblage, including Glaphyrocysta sp., Rhombodinium sp., Chiropteridium sp., Caligodnium sp., Wetzeliella symmetrica, and Deflandrea phosporitica and AOM is also more homogeneous relative to sample A 1040a. Examination in UV light showed that the palynomorphs have dark yellow and orange fluorescence colours. Additionally, UV fluorescence demonstrated the presence of freshwater algae: namely, Botryococcus sp., Pediastrum sp. and Pterospermella sp. (Fig. 6N), which were not seen in transmitted light.

Sample A 1042cz, collected from clasts within the Slon Beds, is dominated by dark orange AOM with weak or no UV fluorescence. The dinoflagellate cysts in this sample are rare and char- 
Relative abundances of SOM recognized in this study

\begin{tabular}{|c|c|c|c|c|c|c|c|c|c|c|c|}
\hline Sample & Lithology & 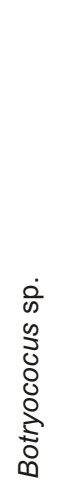 & $\begin{array}{l}\frac{0}{0} \\
\frac{\mathrm{J}}{5} \\
0\end{array}$ & 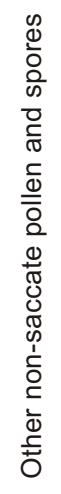 & 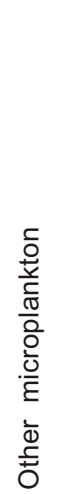 & 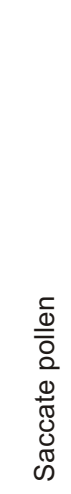 & $\begin{array}{l}\stackrel{\complement}{\mathscr{D}} \\
\mathscr{\Perp}\end{array}$ & 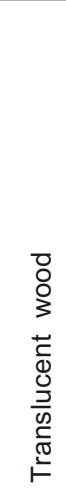 & $\begin{array}{l}\overline{0} \\
0 \\
3 \\
0 \\
0 \\
0 \\
0 \\
0 \\
0\end{array}$ & $\sum_{0}$ & 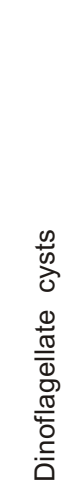 \\
\hline DP 10 & black shale & 0.0 & 0.0 & 0.3 & 0.0 & 0.0 & 0.0 & 0.3 & 4.0 & 95.4 & 0.0 \\
\hline DP 9B & grey mudstone & 0.0 & 0.0 & 0.0 & 0.0 & 0.0 & 0.0 & 0.3 & 6.9 & 92.8 & 0.0 \\
\hline DP 9A & black shale & 0.0 & 0.0 & 0.0 & 0.0 & 0.0 & 0.0 & 0.3 & 12.8 & 86.9 & 0.0 \\
\hline DP 8B & black mudstone & 0.0 & 0.0 & 0.0 & 0.0 & 0.0 & 0.0 & 0.0 & 0.3 & 99.7 & 0.0 \\
\hline DP 8A & grey shale & 0.0 & 0.0 & 0.0 & 0.0 & 0.0 & 0.0 & 0.0 & 11.9 & 88.1 & 0.0 \\
\hline DP 7 & black shale & 0.0 & 0.0 & 0.0 & 0.0 & 0.0 & 0.0 & 0.0 & 2.9 & 97.1 & 0.0 \\
\hline DP 6 & black shale & 0.0 & 0.0 & 0.3 & 0.0 & 0.0 & 0.0 & 0.7 & 8.0 & 91.0 & 0.0 \\
\hline DP 5C & black shale & 0.0 & 0.0 & 0.0 & 0.0 & 0.0 & 0.0 & 0.0 & 6.4 & 93.6 & 0.0 \\
\hline DP 5B & grey shale & 0.0 & 0.0 & 0.0 & 0.0 & 0.0 & 0.0 & 0.3 & 7.3 & 92.4 & 0.0 \\
\hline DP 5A & grey mudstone & 0.0 & 0.0 & 0.0 & 0.0 & 0.0 & 0.0 & 0.0 & 6.9 & 93.1 & 0.0 \\
\hline $\mathrm{DP} 4 \mathrm{~B}$ & black shale & 0.0 & 0.0 & 0.0 & 0.0 & 0.0 & 0.0 & 0.0 & 1.6 & 98.4 & 0.0 \\
\hline DP 4A & grey shale & 0.0 & 1.7 & 0.0 & 0.0 & 0.0 & 0.0 & 0.0 & 16.8 & 81.5 & 0.0 \\
\hline DP 3B & grey shale & 0.0 & 0.0 & 0.0 & 0.0 & 0.0 & 0.0 & 1.6 & 17.8 & 80.6 & 0.0 \\
\hline DP 3A & black shale & 0.0 & 0.0 & 0.0 & 0.0 & 0.0 & 0.0 & 0.3 & 4.8 & 94.9 & 0.0 \\
\hline DP 2 & grey mudstone & 0.0 & 0.0 & 0.0 & 0.0 & 0.0 & 0.0 & 0.0 & 17.5 & 82.5 & 0.0 \\
\hline $\mathrm{DP} 1 \mathrm{~A}$ & black shale & 0.0 & 0.0 & 0.0 & 0.0 & 0.0 & 0.0 & 0.3 & 6.6 & 93.1 & 0.0 \\
\hline S 2 & black shale & 0.0 & 0.0 & 0.0 & 0.0 & 0.0 & 0.0 & 0.0 & 1.3 & 98.7 & 0.0 \\
\hline S 12 & black shale & 0.0 & 0.0 & 0.0 & 0.0 & 0.0 & 0.0 & 0.0 & 1.0 & 99.0 & 0.0 \\
\hline S 16 & black shale & 0.0 & 0.0 & 0.0 & 0.0 & 0.0 & 0.0 & 0.0 & 18.3 & 81.7 & 0.0 \\
\hline S 24 & black shale & 0.0 & 0.0 & 0.0 & 0.0 & 0.0 & 0.0 & 0.0 & 3.1 & 96.9 & 0.0 \\
\hline S 30 & black shale & 0.0 & 0.0 & 0.0 & 0.0 & 0.0 & 0.0 & 0.6 & 6.1 & 93.2 & 0.0 \\
\hline N 1008b & laminated limestone & 0.0 & 0.0 & 0.0 & 0.0 & 0.0 & 0.0 & 1.9 & 0.0 & 97.8 & 0.3 \\
\hline N 1008a & laminated limestone & 0.0 & 0.0 & 0.9 & 0.0 & 1.8 & 0.0 & 0.3 & 0.3 & 96.7 & 0.0 \\
\hline N 1003a & black shale & 0.0 & 0.0 & 0.0 & 0.6 & 1.3 & 0.0 & 0.6 & 0.3 & 97.1 & 0.0 \\
\hline N 1001 & black shale & 0.0 & 0.0 & 0.3 & 0.0 & 0.9 & 0.0 & 3.1 & 0.0 & 90.3 & 5.3 \\
\hline N 1000 & black shale & 0.0 & 0.3 & 9.6 & 0.0 & 10.4 & 0.3 & 12.8 & 10.1 & 43.5 & 13.0 \\
\hline N 993b & black shale & 0.0 & 0.0 & 0.3 & 0.0 & 0.0 & 0.0 & 1.7 & 0.0 & 93.4 & 4.7 \\
\hline N 991 & bituminous marl & 0.0 & 0.0 & 0.0 & 0.0 & 0.0 & 0.0 & 0.0 & 0.0 & 100.0 & 0.0 \\
\hline N 977 & black shale & 0.0 & 0.0 & 0.3 & 0.0 & 1.0 & 0.0 & 0.6 & 6.1 & 88.1 & 3.8 \\
\hline N 971 & brown shale & 0.0 & 0.0 & 1.6 & 0.0 & 2.3 & 1.6 & 3.2 & 2.6 & 75.7 & 12.9 \\
\hline N 962 & brown shale & 0.0 & 0.0 & 0.3 & 0.0 & 0.0 & 0.0 & 0.0 & 0.0 & 99.4 & 0.3 \\
\hline N 961 & bituminous marl & 0.0 & 0.0 & 0.0 & 0.0 & 0.0 & 0.0 & 0.0 & 0.0 & 100.0 & 0.0 \\
\hline N 960 & brown shale & 0.0 & 0.0 & 0.9 & 0.0 & 1.9 & 0.0 & 0.0 & 0.3 & 96.0 & 0.9 \\
\hline N 952 & brown shale & 0.0 & 2.0 & 9.3 & 0.0 & 11.3 & 0.0 & 3.0 & 1.7 & 71.7 & 1.0 \\
\hline N 949 & grey siltstone & 0.0 & 0.0 & 1.0 & 0.0 & 1.3 & 0.3 & 1.6 & 3.5 & 92.3 & 0.0 \\
\hline PN KG & bituminous marl & 0.0 & 0.0 & 0.0 & 0.0 & 0.0 & 0.0 & 0.0 & 1.3 & 98.7 & 0.0 \\
\hline PN SPK & bituminous marl & 0.0 & 0.0 & 0.0 & 0.0 & 0.0 & 0.0 & 4.8 & 9.6 & 85.5 & 0.0 \\
\hline PN PM & shale & 0.0 & 0.0 & 0.0 & 0.0 & 0.0 & 0.0 & 2.5 & 3.1 & 94.4 & 0.0 \\
\hline PN PK & shale & 1.2 & 0.0 & 0.0 & 0.0 & 0.0 & 0.0 & 0.0 & 0.9 & 97.8 & 0.0 \\
\hline A 1040b & shale & 0.3 & 0.0 & 6.8 & 0.0 & 1.5 & 0.9 & 7.1 & 0.3 & 80.5 & 2.7 \\
\hline A 1040a & shale & 1.0 & 0.0 & 4.2 & 0.3 & 8.7 & 0.6 & 1.3 & 1.0 & 82.4 & 0.6 \\
\hline A 1041 & marl & 0.0 & 0.0 & 0.3 & 0.0 & 0.3 & 0.0 & 0.0 & 0.0 & 99.4 & 0.0 \\
\hline A 1042j & breccia matrix & 0.0 & 0.0 & 0.9 & 0.0 & 0.3 & 0.0 & 7.8 & 27.8 & 29.9 & 33.4 \\
\hline A $1042 c$ & clast from breccia & 0.0 & 0.0 & 0.3 & 0.0 & 0.0 & 0.0 & 0.0 & 0.7 & 98.7 & 0.3 \\
\hline
\end{tabular}



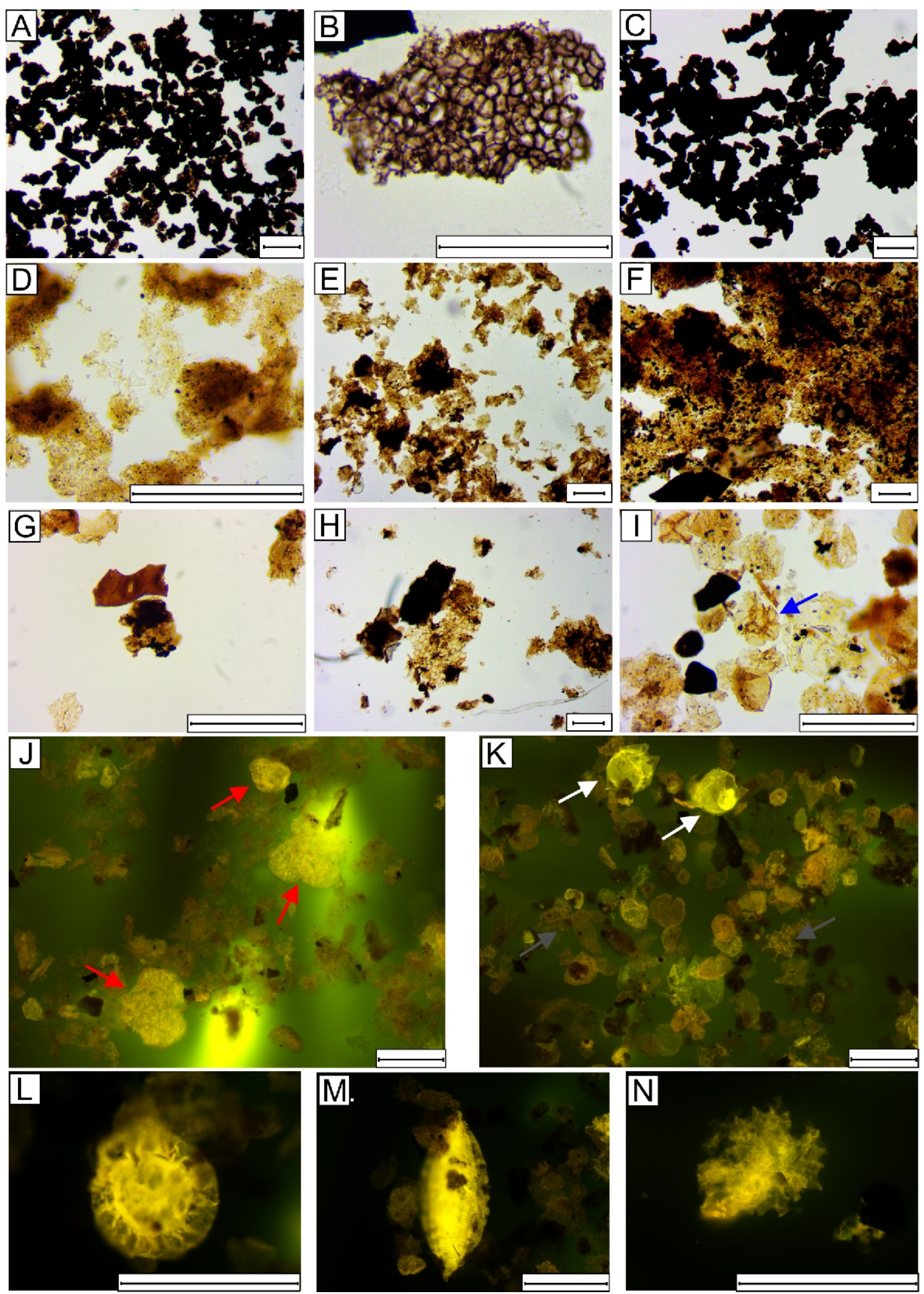

Fig. 6. Palynofacies, phytoclasts and palynomorphs from selected samples

A - palynofacies composed of black AOM and opaque phytoclasts, sample DP 5C; B - dark brown cuticle, DP 4A; C - organic material characterized by the dominance of black AOM, sample S 2; $\mathbf{D}$ - palynofacies composed mainly of pale AOM, sample PN KG; E - palynological material characterized by dominance of yellow AOM, sample N 962; $\mathbf{F}$ - organic material characterized by the dominance of yellow AOM with high pyrite concentrations, sample N 952; G - translucent phytoclast with sharp edges, sample N 977; H - cuticle (in centre), sample N 993b; I - foraminiferal linings (blue arrow), sample N 1000; J-organic material characterized by a great abundance of the freshwater colonial algae Botryococcus sp., sample PN SPK; K - palynological material characterized by palynomorphs with different degrees of preservation, white arrows indicate dinoflagellate cysts identified as Deflandrea phosporitica, with bright yellow fluorescence; grey arrows indicate dinoflagellate cysts with orange fluorescence, sample N 1000; L - Pterospermella sp., sample N 1000; M Campenia sp., sample N 1000; N - Pediastrum sp., sample A 1040a; scale bar on all photographs - $100 \mu \mathrm{m}$ 
acterized by a very poor state of preservation, often hampering identification. The sample includes Enneadocysta pectiniformis, Charlesdowniea coleothrypta, Deflandrea phosporitica, Spiniferites sp. and Cordosphaeridium sp. Examination in UV light showed that the palynomorphs have orange fluorescence. By contrast, in sample A 1042j collected from the sediment matrix, dinoflagellate cysts are the most abundant components of the SOM (Table 3). The sample yielded Enneadocysta pectiniformis, Membranophoridium aspinatum, Deflandrea phosporitica, Homotryblium tenuispinosum, Achomosphaera sp. and Spiniferites sp. Under UV light, all cyst specimens exhibited similar fluorescence colours (Fig. 7I, J).

PIATRA NEAMT

From Piatra Neamt, palynofacies in 4 samples were analysed. The SOM from the samples collected at Piatra Neamt is dominated by AOM (85.5-98.7\%), with a secondary phytoclast component. Translucent (max. 4.8\%) and opaque (max. 9.6\%) wood was identified in all four samples. Sample PN PK differs from other samples due to the presence of Botryococcus sp. $(1.2 \%)$, which was observed in transmitted light. In translucent light, the AOM is characterized by yellow and orange colours. Analysis under UV light revealed an additional freshwater algae taxon, Pediastrum sp., in the samples. In sample PN SPK, a relatively high abundance of Botryococcus sp. was also observed (Fig. 6J).

NECHIT RIVER

From Nechit, palynofacies in 14 samples were analysed. Most samples from the Nechit River section are characterized by a larger degree of variability than in other sections, with AOM as the dominant component (43.5-100\%). In transmitted light, most of the AOM shows bright colours, with pyrite present. Samples where AOM was the only type of SOM (N 961 and N 991) were collected from the Dynów Marl. UV light analysis showed that the AOM in these two samples has weak or absent fluorescence and a structureless nature. Therefore, it is not possible to identify primary elements present in the AOM. In some other samples, UV analysis revealed the presence of various components hosted within the AOM: sporomorphs (sample N 952; Fig. 7A) and palynomorphs (sample N 1000). Analysis of organic matter under UV light also allowed for the identification of freshwater algae in the following samples: N 1000 (Botryococcus sp., Pterospermella sp., Campenia sp.; Fig. 6L, M), N 1003a (Botryococcus sp.) and N 1008a (Botryococcus sp.).

Samples N 971 and N 1000 are characterized by a higher abundance of dinoflagellate cysts (12.9 and $13 \%$, respectively) relative to other samples. The dinoflagellate cysts in these two samples are poorly preserved and are possibly reworked [sample N 971: Areosphaeridium diktyoplokum (Fig. 7M) and Cerodinium wardenense (Fig. 7D, E); sample N 1000: Areosphaeridium diktyoplokum (Fig. 7G)]. Sample N 993b, collected above a bed with typical combined flow structures, including hummocky cross-stratification (Fig. 5C, D), contains cuticle fragments (Fig. 6H). In samples N 949, N 971, N 1000 resin was also identified.

\section{INTERPRETATION}

In spite of the large present-day distance $(100 \mathrm{~km})$ between the Slovakian Menilite Beds exposures (Dara Prislop and Smilno), their organic matter has similar properties. In all sam- ples, the AOM is dominated by granular, dark brown or black aggregates. Opaque phytoclasts are the second most common component of the SOM (Fig. 5). The black and brown colours of AOM, cuticles, and Tasmanites sp. imply a high degree of thermal maturation (i.e., post-mature source rock). The results from Slovakia are probably related to the relatively high geothermal activity in the region, known as the Carpathian Conductivity Anomaly (Majcin et al., 2014). This high heat flux was associated with a deep-seated fault system on the margin of the European Platform (Kucharič et al., 2013; Majcin et al., 2014). This fault system is thought to be responsible for the formation of Cenozoic volcanic rocks and active heat transfer through fluid mobilization, which additionally may increase thermal maturity (Majcin et al., 2014).

The SOM assemblages from the selected Romanian exposures are characterized by high AOM abundances. In contrast to the AOM from the Slovakian sections, their AOM is pale yellow to orange, with the common presence of pyrite. The samples from Romanian sections are also characterized by a larger diversity of organic matter components (in some samples, seven component types are present, of both marine and terrestrial origin) than the samples from Slovakia. Together, this suggests that the Slovakian Menilite Beds were deposited in the centre of the basin, at a greater distance from the organic matter source area than the Vrancea Menilite Beds (Romania). In contrast, the results from Nechit and Piatra Neamt suggest that the Vrancea Menilite Beds were deposited in the marginal part of the basin. An AOM-palynomorph-phytoclast ternary plot suggests that the Menilite Beds were deposited under distal, suboxic-anoxic conditions (Fig. 8). However, the presence of cuticle in these samples is indicative of a relatively proximal depositional setting (Tyson, 1993). This is due to the leaf origin of cuticle, which cannot be transported for long distances because it is extremely prone to mechanical degradation and bacterial decomposition, causing it to rain out of the water column (Spicer, 1991). As an exception, cuticle particles can occur in deep-water environments when they are funnelled down submarine canyons (Shepard, 1964; Cross et al., 1966; Schnyder, 2017). Within the Menilite Beds, the Cergowa Beds are considered to be submarine fan deposits (e.g., Pszonka and Wendorff, 2017). This lithostratigraphic unit was analysed in the Dara Prislop exposure, where typical turbidity current structures were identified, including graded intervals, load structures, convolute bedding, tool marks, and flute marks. In sample DP 4A, from grey sandy mudstones in the lower part of the package characterized by normal grading, cuticle fragments were observed. The preservation of these easily degraded plant remains may have been due to rapid deposition and burial in turbiditic sediments.

In the Vrancea Unit, cuticle fragments were also identified. Moreover, typical submarine fan structures were not observed in this region. Therefore, the deposition of the Menilite Beds in the Nechit River area is unlikely to have occurred in a deep-water setting, because cuticle fragments, which are prone to bacterial decomposition, causing them to rain out of the water column, are present in samples. This is supported by the lithology of the Nechit River exposure: namely, the presence of hummocky cross-stratification structures generally interpreted as indicative of storm wave base conditions (Duke et al., 1991; Dumas and Arnott, 2006; Fig. 5D). Moreover, storm conditions can introduce and preserve plant fragments through rapid transport and provide good burial conditions (Spicer, 1980). Such conditions are probably documented in sample N 993b (Fig. 5D), in which cuticle fragments were common. Tyson (1993) suggests that similar organic matter assemblages, with domination of $\mathrm{AOM}$ and low percentages of palynomorphs, may 

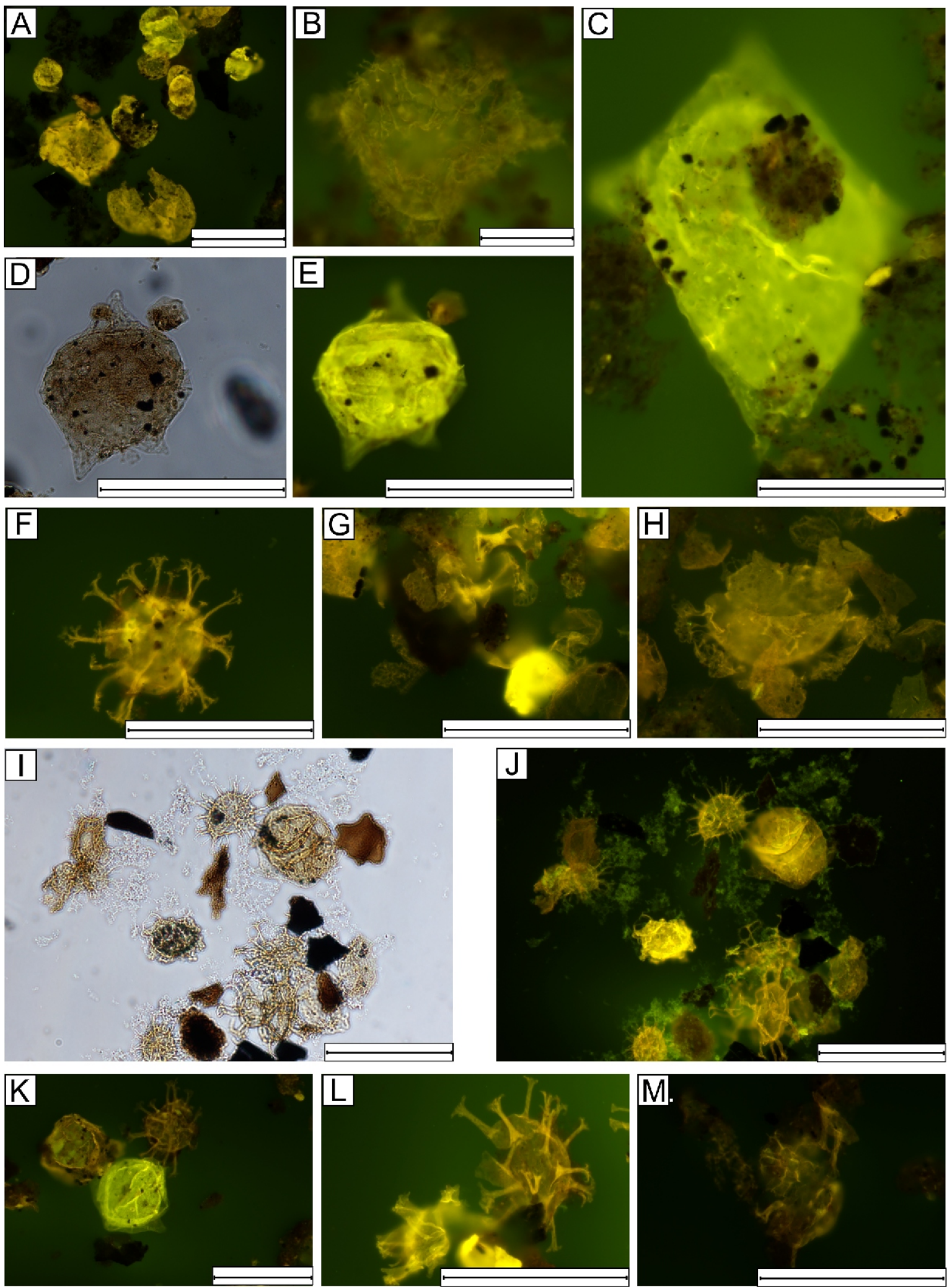

Fig. 7. Palynomorphs and sporomorphs from the Menilite $(A-H, K-M)$ and Slon beds (I-J)

A - bisaccate pollen grains, sample N 952; B - Wetzelliela articulata, sample N 962; C - Rhombodinium freienwaldense, sample N 960; D, E - Cerodonium wardenense, N 971; F - Hystrichosphaeridium tubiferum, sample N 1000; G Areosphaeridium diktyoplokum, sample N 1000; H - Glaphyrocysta sp., N 1000; I-dinoflagellate cysts from the Slon Beds in transmitted light, sample A 1042j; J - dinoflagellate cysts from the Slon Beds in UV light, sample A 1042j; K, L dinoflagellate cyst with two styles of fluorescence, sample N 971; M - Reticulatosphaera actinocoronata and Areosphaeridium diktyoplokum, sample N 971; scale bar on all photographs - $100 \mu \mathrm{m}$ 


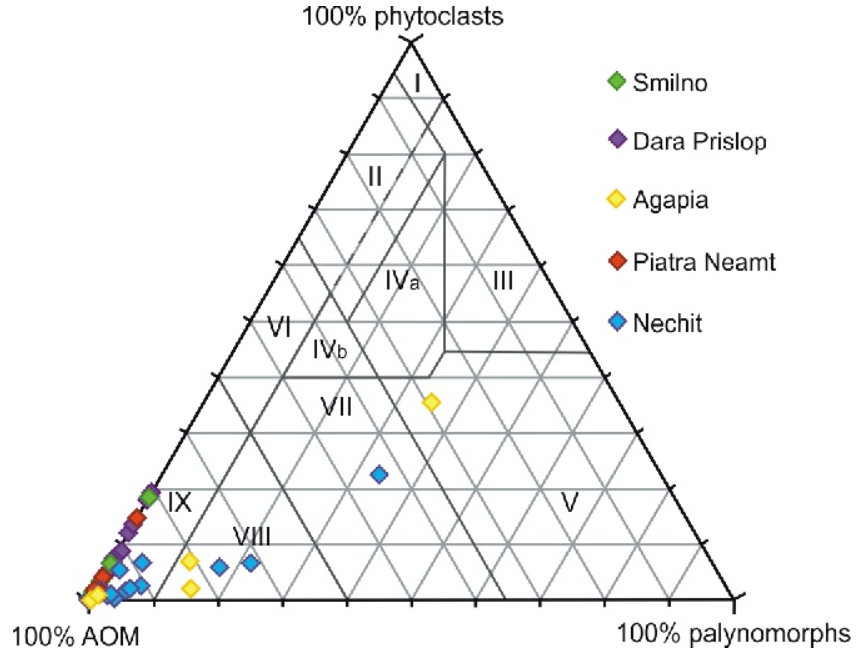

Fig. 8. AOM-palynomorph-phytoclast ternary plot (after Tyson, 1989)

Palynofacies fields: I - highly proximal shelf or basin, II - marginal dysoxic-anoxic basin, III - heterolithic oxic shelf ("proximal shelf"), IV - shelf to basin transition, $\mathrm{V}$ - mud-dominated oxic shelf ("distal shelf"), VI - proximal suboxic-anoxic shelf, VII - distal dysoxic-anoxic "shelf", VIII - distal dysoxic-anoxic shelf, IX - distal suboxic-anoxic basin

also be characteristic of stratified shelf seas. This interpretation is supported by geochemical investigations (Kotarba et al., 2013; Sachsenhofer et al., 2015; Bojanowski et al., 2018). Water column stratification might have been induced by basin isolation and subsequent freshwater influx, as in the case of the modern Black Sea (e.g., Murray et al., 1989). As a result, zones with reduced salinity and large-scale freshwater algae growth might have occurred in proximal settings within the basin.

Notably, freshwater algae have been identified in the Romanian sections. In the Vrancea Unit (Romania), the green algae Botryococcus sp. and Pediastrum sp. and the prasinophytes Pterospermella sp. and Campenia sp. are found, whereas in Smilno (Slovakia) only the prasinophyte Tasmanites sp. occurs. Botryococcus comprises a group of colonial green algae abundant in freshwater and brackish settings (e.g., lakes, seas, ponds; Metzger and Largeau, 2006; Mendonça Filho et al., 2012). Mobile mats with thicknesses of up to several centimetres and areas of hundreds of square metres may be formed during Botryococcus blooms (Guy-Ohlson, 1992). As a typical freshwater colonial form, Botryococcus may be transported by rivers to basins (Caratini et al., 1983; Guy-Ohlson, 1992), where it can co-occur with marine palynomorphs. Representatives of the extant genus Pediastrum mainly occur in freshwater environments: they are rarely found in brackish-water basins and these sparse appearances are related to freshwater influxes at river mouths (Komárek and Jankovská, 2001). Pterospermella sp. is also interpreted as an indicator of reduced surface salinity (Mudie, 1992; Below and Kirsch, 1997). In the framework of the Menilite Beds, these algae have also been identified in Poland, in the western part of the Silesian Unit.

By contrast, representatives of the genus Tasmanites are euryhaline, eurythermal marine algae found in a broad diversity of environments (Guy-Ohlson, 1988). Consequently, these algae can be regularly recovered from widely differing sedimentary facies (Guy-Ohlson, 1988). There are also reports that link Tasmanites sp. to eutrophic waters with regular and ample nutrient supply (Vigran et al., 2008).
The presence of these algal genera points to the existence of zones with significantly reduced salinity during the deposition of the Menilite Beds. Comparatively large variability in organic matter composition, and the presence of typical freshwater algae (Pediastrum sp., Pterospermella sp.) and algae tolerant of low-salinity settings (Botryococcus sp.), were observed in the marginal Outer Carpathians (Vrancea Unit). In contrast, the internal Outer Carpathians (Dukla and Grybów units) are characterized by low organic matter variability and the presence of only Tasmanites sp., which has a higher tolerance to salinity than Botryococcus sp., Pediastrum sp. and Pterospermella sp. The presence of those diagnostic algae and sedimentological observations suggest that the deposition of the Menilite Beds in the Vrancea Unit occurred in a marginal zone at a relatively short distance from the shoreline, above storm wave base. However, the deposition of the Menilite Beds at Dara Prislop and Smilno occurred farther from the shore in a more central part of the basin where salinity was higher than in its marginal zones.

Poor preservation of reworked palynomorphs (Areosphaeridium diktyoplokum, Cerodinium wardenense) may be a consequence of physical deterioration, as the result of transport processes during redeposition and the growth of pyrite crystals within. Some authors have found Areosphaeridium diktyoplokum in Lower Oligocene deposits (e.g., Maier, 1959; Śliwińska et al., 2012). However, poor preservation of Areosphaeridium diktyoplokum and co-occurrence with Cerodinium wardenense indicate that they are probably redeposited. UV analysis of samples from Nechit reveal differences in the fluorescence colours of palynomorphs and sporomorphs (Fig. 6K), testifying to the reworking of some palynomorphs and sporomorphs from older rocks and the presence of two distinct SOM groups with different thermal maturities (Figs. $6 \mathrm{~K}$ and $7 \mathrm{~K}, \mathrm{~L}$ ). Additionally, samples without reworked specimens are dominated by peridinioid cysts (mainly Wetzelielloidae; Fig. 6B, C), whereas samples N 971 and N 1000, in which reworked palynomorphs were identified, are dominated by gonyaulacoid cysts (Figs. 6F, $7 G, K-M)$. Indeed, sample N 971 contains three types of palynomorph fluorescence (yellow, orange, dark orange; Fig. 7). However, contrary to the general paradigm of UV fluorescence interpretation (Hartkopf-Fröder et al., 2015), a case was identified where older cysts (Cerodinium werdenense) are characterized by lighter fluorescence colours than younger cysts (e.g., Reticulatosphaera actinocoronata) characteristic of the Oligocene. This variability may be linked to reworking from rocks with internally diverse thermal histories. Similar fluorescence variability was observed in sample N 1000, where Eocene dinoflagellate cysts were observed; furthermore, different UV light colours were noted among sporomorphs as well (Fig. 6K). The reworking of organic particles from older rocks is likely to have caused much greater variability of SOM than in samples devoid of reworked material.

\section{ASSESSMENT OF THE HYDROCARBON POTENTIAL OF THE MENILITE BEDS}

The high thermal maturity observed in samples from the Dara Prislop and Smilno sections (Slovakia) suggests that hydrocarbons were probably generated or thermally decomposed from these parts of the Menilite Beds. The results support biomarker analysis, which suggests that the Menilite Beds in inner tectonic units are overmature (Kotarba et al., 2007; Kosakowski et al., 2018). The organic matter from the Vrancea Unit Menilite Beds is between 2.5 and 6.5 (Fig. 6B) on the Spore Colour Index Chart (Fischer et al., 1980), which indicates that it 
is either immature or in the initial oil window (Waples, 1985; Marshall, 1990). The high hydrocarbon potential of the Menilite Beds is reflected in the presence of abundant AOM (of marine/algal origin) and of algae (Tasmanites sp., Botryococcus sp., Campenia sp.), especially in the Vrancea area. All these algae - but in particular Botryococcus sp. and Campenia sp. have an ability to synthesise and accumulate lipid substances, including hydrocarbon precursors (Metzger and Largeau, 2006). However, UV light analysis of exposures of Romanian Menilite Beds show very bright fluorescence colours, indicative of a low degree of thermal maturation. My interpretation agrees with previous geochemical investigations (Wendorff et al. 2017). This may imply that parts of the Menilite Beds with high potential for hydrocarbon generation may exist in deep structures within the Romanian Outer Carpathians, where the top of the Menilite Beds in the Vrancea Unit is located at an average depth of $2.5 \mathrm{~km}$ (Dicea, 1995; Popescu and Anastasiu, 2017). Kosakowski et al. (2018) envisaged a similar situation in the Boryslav-Pokuttya Unit in Ukraine, where the organic matter from exposures of the Menilite Beds is generally immature. However, the Menilite Beds buried between 3 and $6 \mathrm{~km}$ in the Boryslav-Pokuttya Unit are located in the oil and gas windows. This may be a sign that hydrocarbons were also generated from the Menilite Beds in the Vrancea area. To test this idea, palynofacies studies and UV light analysis should be performed on core samples collected from Menilite Beds, which exist at depth in this region.

\section{DEPOSITIONAL ENVIRONMENT OF THE MENILITE BEDS}

Studies of the Outer Carpathians have previously interpreted the flysch-like deposition of the Outer Carpathians succession as having mainly occurred in deep-marine settings (Książkiewicz, 1975; Unrug, 1979; Van Couvering et al., 1981; Leszczyński and Uchman, 1991; Kotlarczyk et al., 2006; Barwicz-Piszkorz and Rajchel, 2012; Oszczypko et al., 2015). In this framework, the Menilite Formation, in particular, was supposedly deposited in the distal parts of turbidite systems and in a pelagic environment on a continental slope, submarine ridges, and an abyssal plain associated with the development of submarine fans through time (Kotlarczyk and Leśniak, 1990 Puglisi et al., 2006; Prekopová and Janočko, 2009; Kotlarczyk and Uchman, 2012).

In contrast to this view, Baldi (1980), Van Couvering et al. (1981), and Rögl (1998) suggested that the deposition of the Menilite Beds took place in a basin isolated from the open ocean. As a consequence of this setting, periodically anoxic conditions developed, and black bituminous shales were deposited in deep-marine depositional settings (Kotlarczyk et al., 2006; Kotlarczyk and Uchman, 2012). Kotlarczyk and Uchman (2012) related anoxia at the sea bottom primarly to water-column stratification and partially to upwelling. Ichthyological analysis of the Outer Carpatian showed that different ecological groups of meso- and bathypelagic fish existed, indicating a depth in the 200-2000 m interval (Kotlarczyk et al., 2006 Kotlarczyk and Uchman, 2012). However, in the Polish (Skole Unit) and Romanian (Vrancea Unit) Outer Carpatians, several shallow-water fish taxa (e.g., flatfish), and taxa tolerant of brackish water fluxes have also been identified (Paucă, 1931; Kotlarczyk et al., 2006; Baciu et al., 2016). Based on foraminiferal assemblages, Olszewska (1985) interpreted the Menilite Beds to have been deposited between the sublittoral and the upper bathyal zones. Moreover, in the past two decades some authors have distinguished shallow and shelf areas during the deposition of the Menilite Beds, primarily on the basis of purely sedimentological investigations (Miclăuş et al., 2008, 2009; Dziadzio et al., 2016; Dziadzio, 2018; Dziadzio and Matyasik, 2018) and sedimentological observations in general geological papers (Watkinson et al., 2001; Jarmołowicz-Szulc and Jankowski, 2011).

A few studies suggested that salinity decreased during the deposition of the Menilite Beds (Kotlarczyk and Kaczmarska, 1987; Melinte, 2005; Garecka, 2012; Studencka et al., 2016). Carbonate units are characterized by the presence of brackish calcareous nannoplankton, bivalves, and the freshwater fish Barbus sp., as well as marine fish (Melinte, 2005; Kotlarczyk et al., 2006; Garecka, 2012; Studencka et al., 2016). Considerable freshwater influxes are also inferred in the present study. Freshwater algae - i.e., Botryococcus sp., Pediastrum sp. and Pterospermella sp. - were recognized in the Piatra Neamt, Agapia, Nechit, and Dara Prislop sections. However, freshwater algae were not observed in the Dynów Marl, probably because the samples were dominated by structureless AOM. Sachsenhofer et al. (2015) suggested that the MTTC ratio (0.32-0.85) indicates reduced and enhanced salinity during $\mathrm{Bi}-$ tuminous Marls deposition.

Changes in sedimentary conditions within the Carpathian basin(s) in the Oligocene were driven by oscillations in relative sea level, in turn resulting from eustatic changes (Popov et al., 2010) and/or transformation of the basin as a result of regional tectonism (Jankowski and Probulski, 2011). According to these hypotheses, changes in the tectonic regime and an ongoing, multistage reconstruction of the basin resulted in a constantly variable basin morphology. The deposition of the Menilite Beds took place during the reorganization of the seaway and the extensional stage of basin development, indicated by the presence of synsedimentary faults (Jankowski and Probulski, 2011). The oldest part of the Menilite Beds was deposited in the earliest Rupelian (Olszewska, 1985). At this time, the Paratethys experienced a eustatic sea level rise followed by isolation of the basin (Baldi, 1980; Haq, 1981; Van Couvering et al., 1981; Rögl, 1998; Popov et al., 2010). Substantial freshwater input and a reduced supply of saline water drove the formation of low-salinity regions in the marginal parts of the Paratethys.

Tyson et al. (1979) suggested that stratified water columns develop in basins with high freshwater supply, reducing the efficiency of vertical mixing processes and driving the development of anaerobic conditions at the sediment-water interface. Limestone and marl horizons containing calcareous nannoplankton may represent the terminal stage in the development of anaerobic conditions (Tyson et al., 1979). In the Menilite Basin, the equivalent limestone and marl deposits are represented by the Tylawa Limestones and the Dynów Marl. Prevalent anoxic conditions during the deposition of the Dynów Marl drove an elevated concentration of fine AOM, within which specific sedimentary organic partciles cannot be identified, even under UV light. Considerable support for this notion comes from Bojanowski et al. (2018) and focuses on the coccolith limestones from the Menilite Beds: here, samples with abundant $\mathrm{AOM}$ are barren with regard to palynomorphs. Tyson et al. (1979) suggested that coccolith blooms are induced by high nutrient supply to the euphotic zone and shallower water depths, leading to a cyclic lithological pattern: clay (oxygenated bottom water conditions), to bituminous/oil shale (anaerobic/intermittently anaerobic bottom water conditions), to coccolith limestone (convective mixing which stimulates coccolith blooms). In this framework, the preservation of laminations in marls and 
limestones is indicative of hemipelagic or pelagic deposition, and large accumulations of pyrite within AOM point to deposition during the acme of anoxic conditions (Tyson et al., 1979). Sachsenhofer et al. (2015) suggested that organic matter from the Bituminous Marls in the Tazlau section, which is located $\sim 8 \mathrm{~km}$ from Nechit, contains a large amount of chrysophyte algae, probably dinoflagellatas. However, based on this biomarker analysis (without specifying the species) it is not possible to determine depositional settings.

The palynofacies and sedimentology of the exposures selected in Slovakia and Romania indicate that the Menilite Beds were deposited in distinct sedimentary settings. Hummocky cross-stratification structures in the Vrancea Unit (Miclăuş et al., 2009, and the present study) suggest a relatively shallow-water depositional environment. However, hummocky cross-stratification can be also found in other depositional environments, such as turbidite sequences (e.g., Mulder et al., 2009; Tinterri and Muzzi Magalhaes, 2011), shoreface-offshore (e.g., Handford, 1986), fan-delta (e.g., DeCelles and Cavazza, 1992; Uroza and Steel, 2008), river-delta (e.g., Leithold and Bourgeois, 1984; Plint and Norris, 1991), fluvial (Browne and Plint, 1994), lacustrine (Eyles and Clark, 1986), and even pyroclastic deposits (e.g., Fisher, 1990). Moreover, a variety of hummocky cross-stratification formation mechanisms exist: they can be caused by oscillatory, combined, or unidirectional flows, related to the oscillation of the wave-base location of the surface or internal waves (e.g., Myrow et al., 2002; Pomar et al., 2012). Therefore, interpretation of hummocky cross-stratification type structures should be combined with other sedimentological and/or palaeoecological records. For this reason, these structures together with cuticle fragments and fragmented and reworked palynomorphs are interpreted here as an indicator for relatively shallow-water environments, probably oscillating around storm wave-base. Additionally, the presence of cuticle fragments in samples above hummocky cross-stratification points towards a relatively short distance from the source area. Cuticle fragments were also identified in Tazlau section, which is located a short distance from Nechit (Sachsenhofer et al., 2015). At the same time, simultaneous water column stratification and anaerobic sediment-water interfaces prevailed in some parts of the basin (e.g., Bojanowski et al., 2018). In the Vrancea Unit, cherts are present. The origin of these cherts may be explained by the diagenetic transformation of diatomites - specifically, transformation of the opal within the diatom frustules (Kaczmarska and Kilarski, 1979; Krhovský, 1981b; Vetö and Hetényi, 1991). Diatomites are predominantly composed of freshwater species, such as Melosira islandica (Krhovský, 1981a). It is likely that the composition of diatomites is related to coastal blooms in regions where salinity was reduced. The presence of freshwater algae (Botryococcus sp., Pediastrum sp., Pterospermella sp.) support these conclusions.

Meyers (1997) compared the conditions of marine nearshore zones to lacustrine settings. Their common characteristics include a large supply of continental organic matter (e.g., phytoclasts, cuticle fragments, sporomorphs), relatively high sedimentation rates, and reduced salinity. Similar conditions could have potentially occurred during the deposition of the Menilite Beds, allowing for the appearance of algae typically characteristic of brackish environments and the development of depositional cycles in relatively shallow parts of the basin susceptible to depth changes, with a constant supply of terrestrial nutrients and clastic material.

In the Dara Prislop exposure, stacked fining-upwards sequences with load structures and sole marks were observed, potentially indicative of deposition during turbidite activity along horst slopes. The samples from Dara Prislop and Smilno are characterized by a low diversity of organic matter (Table 3 and Fig. 6A, C). This may be associated with fast depositional rates, resulting from turbidity current sedimentation and the preferential preservation of components resistant to mechanical degradation (e.g., opaque wood). In the Slovakian sections (Smilno, Dara Prislop), only a few terrestrial organic particles were identified (cuticle particles in DP 4A and spores in DP 10). Additionally, the presence of Tasmanites sp., which may occur in waters with higher salinity than Botryococcus sp. and Pediastrum sp., suggests the Dara Prislop and Smilno (Slovakia) sections were probably located farther from the source area of organic matter influx than the Vrancea area. It should be emphasized, though, that the source areas might be different as well. That is why palynofacies and sedimentological analysis should be carried out in a larger area of the Outer Carpathians. This will allow for constraints on the sediment transport directions during deposition of the Menilite Beds.

If the presence of several sedimentary basins, as opposed to a unitary basin, in the Outer Carpathians is assumed, the distribution of organic matter indicates the presence of Paratethys shallow-water zones with reduced salinity during the deposition of the Menilite Beds in the outermost basin, associated with freshwater influxes adjacent to river mouths. In the Dara Prislop and Smilno area, located in the inner basin (Dukla Basin), the low diversity of organic components indicates the absence of proximal terrestrial areas and considerable distances from the source area. However, Cergowa Beds type deposits pinpoint the presence of elevated areas, probably submarine highs.

The occurrence of several deep-water adjacent sub-basins, separated by subaqueous to subaerial elevations, would be reflected in repetitions in the nature of organic matter distribution (a decrease in organic matter component diversity and the disappearance of terrestrially derived particles with greater distance from the source area). Gagała et al. (2012) suggested that the minimum orogenic shortening of the Outer Carpathians was $\sim 507 \mathrm{~km}$. In this context, the width of the Outer Carpathians basin(s) was probably $\sim 700 \mathrm{~km}$. Therefore, the development of several deep-water basins seems unlikely.

In the semi-isolated, multiple sub-basin model, the Slovakian samples would expect a larger number and greater diversity of terrestrial particles (e.g., pollen, spores, resins, cuticle fragments, translucent wood) or reworked organic matter from submarine highs/land areas. Their absence may suggest that the deposition of the Menilite Beds took place in a large, more or less morphologically diverse basin (with potential submarine highs), with a centre in Slovakia and marginal elements in Vrancea. To test this model, integrated analysis (including sedimentological and palynofacies studies) should be carried out in units to the north of Dara Prislop and Smilno and to the west of the Vrancea Unit. This will allow a more precise reconstruction of basinal development and of the depositional settings of the Menilite Beds.

\section{CONCLUSIONS}

A detailed palynofacies analysis of 42 samples from the 23 exposures in the Menilite Beds of the Romanian (21 samples) and Slovakian (21 samples) Outer Carpathians was conducted. These samples represent various lithologies (siltstones, mudstones, limestones, marls). Additionally, two samples from the overlying Slon Beds (Agapia area in Romania) were investigated. The SOM content of the Menilite Beds from Dara Prislop, Smilno, and the Vrancea Unit areas provides insight into the regional depositional environment during the Oligocene. The following observations are of particular importance: 
1. The palynofacies show great $A O M$ abundances in all samples studied. In samples with reworked palynomorphs (e.g., dinoflagellate cysts and sporomorphs), a larger variability of organic matter components and reduced AOM content is noted.

2. UV-light analysis allowed for the identification of dinoflagellate cysts, sporomorphs, and freshwater algae (Botryococcus sp., Campenia sp., Pediastrum sp. and Pterospermella sp.), which are generally not visible in transmitted light. The presence of freshwater algae points to the existence of zones with reduced salinity during the deposition of the Menilite Beds. It is likely these zones were associated with freshwater influxes adjacent to river mouths.

3. Palynofacies results, organic matter observations under UV light, and sedimentological observations (e.g., hummocky cross-stratification) suggest that a relatively shallow-water (above storm wave base), brackish environment prevailed during deposition of those Menilite Beds presently exposed in the Vrancea Unit, which is among the marginal units of the Outer Carpathians.

4. The Menilite Beds deposits in Slovakia (Dukla Unit - internal Carpathian Unit) were deposited farther from the source area than those of the Vrancea Unit (external Carpathian Unit).

5. The presence of algae (Tasmanites sp., Botryococcus sp., Campenia sp.) characterized by the ability to syn- thesise and accumulate lipid substances, including hydrocarbon precursors, points to a high hydrocarbon potential. However, palynomorph colours in both transmitted and UV light are indicative of thermal immaturity in the Vrancea Unit. By contrast, the dark colours of palynomorphs and AOM from Dara Prislop and Smilno indicate that in the Slovakian exposures, organic matter in the Menilite Beds is characterized by a high degree of thermal maturity, related to the occurrence of the Carpathian Conductivity Anomaly zone in this region.

Acknowledgements. Cordial thanks are offered to A. Wysocka (University of Warsaw, Poland), L. Jankowski (Carpathian Branch, Polish Geological Institute - National Research Institute, Poland) and M. Barski (University of Warsaw, Poland), whose constructive remarks significantly improved the content of the paper. Fieldwork was conducted with the help and guidance of $\mathrm{L}$. Jankowski, who provided many helpful comments on the geology of the Outer Carpathians. Furthermore, the author thanks A. Maksym (Polish Oil and Gas Company, Poland) for help in fieldwork at the Smilno locality, and D. Cybulska and D. Zaszewski (both from the University of Warsaw, Poland) for graphical help. Last, but not least, I would like to thank the reviewers of this manuscript, K. Śliwińska (Geological Survey of Denmark and Greenland), M. Garecka (Polish Geological Institute) and Y.V. Koltun (National Academy of Sciences of Ukraine).

\section{REFERENCES}

Anastasiu, N., 2016. Standard source rocks in the Romanian petroleum systems - an overview. Proceedings of the Romanian Academy, Series B, 18: 121-136.

Andreyeva-Grigorovich, A.S., Gruzman, A.D., 1994. The biostratigraphic basis of the Paleogene-Neogene boundary in the Central (Ukrainian Carpathians) and Eastern (Black Sea Depression, Northern Caucasus) Paratethys. Geologica Carpathica, 45: 333-342.

Andreyeva-Grigorovich, A.S., Kulchysky, Y.O., Gruzman, A.D. Lozynyak, P.Y., Petrashkevich, M.I., Portnygina, L.O. Ivanina, A.V., Smirnov, S.E., Trifomovich, N.A., Savitskaya, N.A., Shvareva, N.J., 1997. Regional stratigraphic scheme of Neogene formations of the Central Paratethys in the Ukraine. Geologica Carpathica, 48: 123-136.

Andrusov, D., 1968. Grundriss der Tektonik der nördlichen Karpaten. Verlag der slowakischen Akademie der Wissenschaften.

Baciu, D.S., Grădianu, I., Seserman, A., Dumitriu, T.C., 2016 Oligocene fish fauna and sedimentological particularities of the Bituminous Marls of the Vrancea Nappe, Eastern Carpathians Romania. Analele Universitătii „Al. I. Cuza” din Iaşi - Seria Geologie, 62: 29-46.

Badescu, D., 1997. Tectono-thermal regimes and lithosphere behaviour in the External Dacides during Upper Triassic and Jurassic Tethyan opening (Romanian Carpathians). Tectonophysics, 282: 167-188.

Badescu, D., 1998. Geology of the East Carpathians - an overview. Reports on Geodesy, 7: 49-69.

Baldi, T., 1980. The early history of the Paratethys. Földtani Közlöny, 110: 456-472.

Balla, Z., 1986. Paleotectonic reconstruction of the central Alpine-Mediterranean belt for the Neogene. Tectonophysics, 127 213-243.
Barwicz-Piskorz, W., Rajchel, J., 2012. Radiolarian and agglutinated foraminiferal biostratigraphy of the Paleogene deep-water deposits on the northern margin of the Carpathian Tethys (Skole Unit). Geological Quarterly, 56 (1): 1-24.

Batten, D.J., 1996. Palynofacies and palaeoenvironmental interpretation. In: Palynology: Principles and Applications. American Association of Stratigraphic Palynologists Foundation (eds. J. Jansonius and D. C. McGregor): 1011-1064. Dallas, Texas.

Belayouni, H., Di Staso, A., Guerrera, F., Martín, M.M., Miclăus, C., Serrano, F., Tramontana, M., 2009. Stratigraphic and geochemical study of the organic-rich black shales in the Tarcău Nappe of the Moldavidian Domain (Carpathian Chain, Romania). International Journal of Earth Sciences, 98: 157-176.

Below, R., Kirsch, K.H., 1997. Die Kerogen-Fazies der Tonstein-Blättertonstein-Rythmite des Ober-Barręme/Unter-Apt im Niedersächsischen Becken (Norddeutschland) am Beispiel der Bohrung Hoheneggelsen KB 50. Palaeontographica Abteilung B, 242: 1-90.

Birkenmajer, K., 1977. Major strike-slip faults of the Pieniny Klippen Belt and the Tertiary rotation of the Carpathians. Publications of the Institute of Geophysics, 175: 101-115.

Birkenmajer, K., 1986. Stages of structural evolution of the Pieniny Klippen Belt, Carpathians. Studia Geologica Polonica, 88: 7-32.

Bojanowski, M., Ciurej, A., Haczewski, G., Jakubauskas, P., Schouten, A., Tyszka, J., Bijl, P.K., 2018. The Central Paratethys during Oligocene as an ancient counterpart of the present-day Black Sea: Unique records from the coccolith limestones. Marine Geology, 403: 301-328.

Browne, G.H., Plint, A.G., 1994. Alternating braidplain and lacustrine deposition in a strike-slip setting: the Pennsylvanian Boss Point Formation of the Cumberland Basin, Maritime Canada. Journal of Sedimentary Petrology, 64: 40-59.

Caratini, C., Bellet, J., Tissot, C., 1983. Les palynofaces: représentation graphique, intéręt de leur étude pour les recon- 
structions paleogéographiques. In: Géochimie Organique des Sédiments Marins d'ORGON à MISEDOR (ed. A. Combaz): 327-351. Editions du Centre National de la Recherche Scientifique, Paris.

Ciurej, A., Haczewski, G., 2016. The Sokoliska Limestone, a new regional marker horizon of coccolith laminites in the Oligocene of the Outer Carpathians: diagnostic features and stratigraphic position. Annales Societatis Geologorum Poloniae, 86: 415-427.

Combaz, A., 1964. Les palynofacies. Revue de Micropaléontologie, 7: $205-218$

Cordier, L., 1808. Suite des recherches sur différens produits des volcans. Journal des mines, 23: 55-74.

Cross, A.T., Thompson, G.G., Zaitzeff, J.B., 1966. Source and distribution of palynomorphs in bottom sediments, southern part of Gulf of California. Marine Geology, 4: 467-524.

Csontos, L., Nagymarosy, A., 1998. The Mid-Hungarian line: a zone of repeated tectonic inversion. Tectonophysics, 297: 51-71.

Curtis, J.B., Kotarba, M. J., Lewan, M.D., Więcław, D., 2004 Oil/source rock correlations in the Polish Flysch Carphatians and Mesozoic basement and organic facies of the Oligocene Menilite Shales: insights from hydrous pyrolysis experiments. Organic Geochemistry, 35: 1573-1596.

De Cizancourt, H., 1931. Geology of oil fields of Polish Carpathian Mountains. AAPG Bulletin, 15: 1-41.

DeCelles, P.G., Cavazza, W., 1992. Constraints on the formation of Pliocene hummocky cross-stratification in Calabria (southern Italy) from consideration of hydraulic and dispersive equivalence, grain flow theory, and suspended-load fall out rate. Journal of Sedimentary Petrology, 62: 555-568.

Dicea, O., 1995. The structure and hydrocarbon geology of the Romanian East Carpathian border from seismic data. Petroleum Geoscience, 1: 135-143.

Duke, W.L., Arnott, R.W. C., Cheel, R.J., 1991. Shelf sandstones and hummocky cross-stratification: New insights on a stormy debate. Geology, 19: 625-628.

Dumas, S., Arnott, R.W.C., 2006. Origin of hummocky and swaley cross-stratification - The controlling influence of unidirectional current strength and aggradation rate. Geology, 34: 1073-1076.

Dziadzio, P.S., 2018. Sedimentary environment of the Menilite Beds in the Stróże Thrust Sheet, Silesian Unit, Carpathians (in Polish with English summary). Nafta-Gaz, 11: 813-820.

Dziadzio, P.S., Matyasik, I., 2018. Sedimentary environment and geochemical correlation of the Oligocene deposits from the Dukla and Grybow units. Nafta-Gaz, 6: 423-434.

Dziadzio, P.S., Borys, Z., Kuk, S., Masowski, E., Probulski, J., Pietrusiak, M., Moryc, J., Górka, A., Baszkiewicz, A., Karnkowski, P., Karnkowski, P.H., Pietrusiak, M., 2006. Hydrocarbon resources of the Polish Outer Carpathians - Reservoir parameters, trap types, and selected hydrocarbon fields: a stratigraphic review. AAPG Memoir, 84: 259-291.

Dziadzio, P.S., Matyasik, I., Garecka, M., Szydło, A., 2016. Lower Oligocene Menilite Beds, Polish Outer Carpathians: supposed deep-sea flysch locally interpreted as shelfal, based on new sedimentological, micropaleontological and organic-geochemical data. Prace Naukowe Instytut Nafty i Gazu Państwowego Instytutu Badawczego, 213: 1-120.

Eyles, N., Clark, B.M., 1986. Significance of hummocky and swaley cross-stratification in late Pleistocene lacustrine sediments of the Ontario basin, Canada. Geology, 14: 679-682.

Filipek, A., Wysocka, A., Barski, M., 2017. Depositional setting of the Oligocene sequence of the Western Carpathians in the Polish Spisz region - a reinterpretation based on integrated palynofacies and sedimentological analyses. Geological Quarterly, 61 (4): 859-876.

Fisher, R.V., 1990. Transport and deposition of a pyroclastic surge across an area of high relief: the 18 May 1980 eruption of Mount St. Helens, Washington. GSA Bulletin, 102: 1038-1054.

Fischer, M.J., Barnard, P.C., Cooper, B.S., 1980. Organic maturation and hydrocarbon generation in the Mesozoic sediments of the Sverdup Basin, Arctic Canada. In: Proceeding 4th Interna- tional Palynological Conference 2 (ed. D. C. Bharadway): 581-588. India Birbal Sahni Institute of Palaeobotany, Lucknow.

Froitzheim, N., Plašienka, D., Schuster, R., 2008. Alpine tectonics of the Alps and Western Carpathians. In: The Geology of Central Europe (ed. T. McCann), 2 (Mesozoic and Cenozoic): 1141-1232. The Geological Society, London.

Garecka, M., 2008. Oligocene/Miocene boundary in the Polish Outer Carpathians based on calcareous nannoplankton (in Polish with English summary). Biuletyn Państwowego Instytutu Geologicznego, 432: 1-54.

Garecka, M., 2012. Record of changes in the Oligocene-Miocene sediments of the Menilite-Krosno series of the Skole Unit based on calcareous nannoplankton studies - biostratigraphy and palaeogeographical implications (Polish Outer Carpathians). Biuletyn Państwowego Instytutu Geologicznego, 453: 1-22.

Gągała, Ł., Vergés, J., Saura, E., Malata, T., Ringenbach, J-C, Werner, P., Krzywiec, P., 2012. Architecture and orogenic evolution of the northeastern Outer Carpathians from cross-section balancing and forward modeling. Tectonophysics, 532-535: 223-241.

Glocker, E.F., 1843. Menilitschiefer in Mähren. Amticher. Bericht über die einungzwngiste Versammlung deutchen Naturforschern und aerzte in Gratz in September 1843: 139-141. Gratz.

Golonka, J., Krobicki, M., 2004. Jurassic paleogeography of the Pieniny and Outer Carpathian basins. Rivista Italiana di Paleontologia e Stratigrafia, 110: 5-14.

Golonka, J., Gahagan, L., Krobicki, M., Marko, F., Oszczypko, N., Ślączka, A., 2006. Plate tectonic evolution and paleogeography of the circum Carpathian region. AAPG Memoir, 84: 11-46.

Grasu, C., Catană, C., Grinea, D., 1988. Flişul carpatic. Petrografie şi consideraţii economice (in Romanian). Editura Tehnică, Bucureşti.

Grasu, C., Catană, C., Miclăus, C., Boboş, I., 1999. The Eastern Carpathian Molasse. Petrography and sedimentogenesis (in Romanian). Editura Tehnică, Bucureşti.

Gucik, S., 1980. Carpathian bituminous shales - their origin and potential as energy raw materials (in Polish with English summary). Przegląd Geologiczny, 28: 552-559.

Gucik, S., 1987. Objaśnienia do Szczegółowej mapy geologicznej Polski, 1:50 000, arkusz Krzywcza (1026) (in Polish). Wyd. Geol., Warszawa.

Gucik, S., Wójcik, A., 1982. Objaśnienia do Mapy geologicznej Polski w skali 1:200 000, arkusz Przemyśl - Kalników (in Polish). Instytut Geologiczny, Warszawa.

Guy-OhIson, D., 1988. Developmental stages in the life cycle of Mesozoic Tasmanites. Botanica Marina, 31: 447-456.

Guy-OhIson, D., 1992. Botryococcus as an aid in the interpretation of palaeoenvironment and depositional processes. Review of Palaeobotany and Palynology, 71: 1-15.

Haczewski, G., 1989. Coccolith limestone horizons in the MeniliteKrosno Series (Oligocene Carpathians) - identification, correlation and origin. Annales Societatis Geologorum Poloniae, 59: 435-487.

Handford, C.R., 1986. Facies and bedding sequences in shelf-storm deposited carbonates, Fayetteville Shale and Pitkin Limestone (Mississippian), Arkansas. Journal of Sedimentary Petrology, 56: 703-722.

Hartkopf-Fröder, C., Königshof, P., Littke, R., Schwarzbauer, J., 2015. Optical thermal maturity parameters and organic geochemical alteration at low grade diagenesis to anchimetamorphism: a review. International Journal of Coal Geology, 150-151: 74-119.

Haq, B.U., 1981. Paleogene paleoceanography: Early Cenozoic oceans revisited. Oceanologica Acta, Special Issue: 71-82.

Ionescu, N., 1994. Exploration history and hydrocarbon prospects in Romania. In: Hydrocarbons of Eastern Central Europe. Habitat, Exploration and Production History (ed. B.M. Popescu): 211-248. Springer, Cerlin, Heidelberg.

Jankowski, L., 2004. Rozwój karpackiej pryzmy akrecyjnej - ujęcie koncepcyjne (in Polish). In: LXXV Zjazd Polskiego Towarzystwa Geologicznego „Poszukiwanie węglowodorów jako źródło po- 
stępu w rozpoznaniu budowy geologicznej Karpat, Zapadliska Przedkarpackiego i ich podłoża", Iwonicz, 22-25.09.2004. (eds. P. Dziadzio and A. Uchman): 98-99. Polskie Towarzystwo Geologiczne, Kraków.

Jankowski, L., 2007. Chaotic complexes in Gorlice region (Polish Outer Carpathians) (in Polish with English summary). Biuletyn Państwowego Instytutu Geologicznego, 426: 27-52.

Jankowski, L., 2015. A new history of the evolution of the Carpathian orogeny - controversial point of view (in Polish with English summary). Prace Instytutu Nafty i Gazu, 20: 1-155.

Jankowski, L., Probulski, J., 2011. Tectonic and basinal evolution of the Outer Carpathians based on example of geological structure of the Grabownica, Strachocina and Łodyna hydrocarbon deposits (in Polish with English summary). Geologia, 37: $555-583$.

Jankowski, L., Wysocka, A., 2019. Occurrence of clastic injectites in the Oligocene strata of the Carpathians and their significance in unravelling the Paleogene and Neogene evolution of the Carpathian orogeny (Poland, Ukraine and Romania). Geological Quarterly, 63 (1): 106-125.

Jankowski, L., Kopciowski, R., Ryłko, W., Danysh, V., Tsarnenko, P., Janočko, J., Jacko, S., 2004. Geological Map of the Outer Carpathians: Borderlands of Ukraine and Romania 1:200 000. Państwowy Instytut Geologiczny, Warszawa.

Jankowski, L., Kopciowski R., Ryłko, W., Danysh, V., Hnylko, O., Pavlyuk, M., Tsarnenko, P., Anastasiu, N., Dragan, E., Popa, M., Roban, R., 2007. Geological Map of the Outer Carpathians: Borderlands of Poland, Ukraine and Slovakia, 1:200 000 . Państwowy Instytut Geologiczny, Warszawa.

Jankowski, L., Kopciowski, R., Ryłko, W., Danysh, V., Tsarnenko, P.N., Hnylko, O., 2012. Lithostratigraphic correlation of the Outer Carpathian borderlands of Poland, Ukraine, Slovakia and Romania (in Polish with English summary). Biuletyn Państwowego Instytutu Geologicznego, 449: 87-98.

Janočko, J., Jacko, S. Jr., 1998. Marginal and deep-sea deposits of the Central-Carpathian Paleogene Basin, Spišká Magura region, Slovakia: Implication for basin history. Slovak Geological Magazine, 4: 281-292

Jarmołowicz-Szulc, K., Jankowski, L., 2011. Geochemical analysis and genetic correlations for bitumens and rocks of the black shale type in the Outer Carpathians tectonic units in Southeastern Poland and the adjacent territory (in Polish with English summary). Biuletyn Państwowego Instytutu Geologicznego 444: 73-98.

Jirman, P., Geršlova, E., Pupp, M., Bubik, M., 2018. Geochemical characteristics, thermal maturity and source rock potential of the Oligocene Šitbořice Member of the Menilite Formation in the Ždánice Unit (Czech Republic). Geological Quarterly, 62 (4): 858-872.

Jucha, S., 1969. Les schistes de Jasło, leur importance pour la stratigraphie et la sédimentologie de la série ménilitique et des couches de Krosno (Carpathes flyscheuses) (in Polish with French summary). Prace Geologiczne, 52: 1-128.

Jucha, S., Kotlarczyk, J., 1961. La série des couches à Menilite et des couches de Krosno dans le flysch des Karpates (in Polish with French summary). Prace Geologiczne, 4: 1-115.

Jurewicz, E., 2005. Geodynamic evolution of the Tatra Mts. and the Pieniny Klippen Belt (Western Carpathians): problems and comments. Acta Geologica Polonica, 55: 295-338.

Kaczmarska, I., Kilarski, W., 1979. The structure of Melosira sulcata (Ehr.) Kütz. var. sulcata frustules from Lower Oligocene diatomites from Futoma (Carpathians, Poland). Annales Societatis Geologorum Poloniae, 49: 185-194.

Karnkowski, P., 1999. Oil and Gas Deposits in Poland. Geological Society "Geos", Kraków.

Kazakhashvili, Zh.R., 1984. Paleobiological history of molluscan fauna from the Solenovian horizon of Georgia (in Russian with English summary). Metzniereba, Tbilisi.

Koltun, Y.V., 1992. Organic matter in Oligocene Menilite formation rocks of the Ukrainian Carpathians: palaeonenvironment and geochemical evolution. Organic Geochemistry, 18: 423-430.
Komárek, J., Jankovská, V., 2001. Review of the Green Algal Genus Pediastrum; Implication for Pollen-Analytical Research. Gebrüder Borntraeger Berlin, Stuttgart.

Kosakowski, P., 2013. 1D modelling of hydrocarbon generation and expulsion from Oligocene Menilite source rocks in the San and Stryi rivers region (Polish and Ukrainian Carpathians). Geological Quarterly, 57 (2): 307-324.

Kosakowski, P., Więcław, D., Kotarba, M.J., 2009. Source rock characteristic of the selected flysch deposits in the transfrontier area of the Polish Outer Carpathians (in Polish with English summary). Geologia, 35: 155-190.

Kosakowski, P., Koltun, Y., Machowski, G., Poprawa, P., Papiernik, B., 2018. The geochemical characteristics of the Oligocene - Lower Miocene Menilite Formation in the Polish and Ukrainian Outer Carpathians: a review. Journal of Petroleum Geology, 41: 319-326.

Koszarski, L., Wieser, T., 1960. New tuff horizon in older Paleogene of flysch Carpathians (in Polish with English summary). Geological Quarterly, 4 (3): 749-771.

Koszarski, L., Żytko, K., 1961. Jasło shales within the Menilite-Krosno Series in the Middle Carpathians (in Polish with English summary). Biuletyn Instytutu Geologicznego, 166: 87-232.

Kotarba, M., Koltun, Y.V., 2006. The origin and habitat of hydrocarbons of the Polish and Ukrainian parts of the Carpathian Province. AAPG Memoir, 84: 395-442.

Kotarba, M.J., Więcław, D., Koltun, Y.V., Marynowski, L. Kuśmierek, J., Dudok, I.V., 2007. Organic geochemical study and genetic correlation of natural gas, oil and Menilite source rocks in the area between San and Stryi rivers (Polish and Ukrainian Carpathians). Organic Geochemistry, 38 1431-1456.

Kotarba, M.J., Więcław, D., Dziadzio, P., Kowalski, A., Bilkiewicz, E., Kosakowski, P., 2013. Organic geochemical study of source rocks and natural gas and their genetic correlation in the central part of the Polish Outer Carpathians. Marine and Petroleum Geology, 45: 106-120.

Kotlarczyk, J., 1988. Geology of the Przemyśl Carpathians - "a sketch to the portrait" (in Polish with English summary). Przegląd Geologiczny, 36: 325-333.

Kotlarczyk, J., Kaczmarska, I., 1987. Two diatom horizons in the Oligocene and (?) Lower Miocene of the Polish Outer Carpathians. Annales Societatis Geologorum Poloniae, 57: 143-188.

Kotlarczyk, J., Leśniak, T., 1990. Lower Part of the Menilite Formation and Related Futoma Diatomite Member in the Skole Unit of the Polish Carpathians (in Polish with English summary). Wydawnictwo AGH, Kraków.

Kotlarczyk, J., Uchman, A., 2012. Integrated ichnology and ichthyology of the Oligocene Menilite Formation, Skole and Subsilesian nappes, Polish Carpathians: a proxy to oxygenation history. Paleogeography, Palaeoclimatology, Palaeoecology, 331-312: 104-118.

Kotlarczyk, J., Jerzmańska, A., Świdnicka, E., Wiszniowska, T. 2006. A framework of ichtyofaunal ecostratigraphy of the Oligocene-Early Miocene strata of the Polish Outer Carpathian Basin. Annales Societatis Geologorum Poloniae, 76: 1-111.

Kováč, M., Andreyeva-Grigorovich, A., Bajraktarević, Z., Brzobohatý, R., Filipescu, S., Fodor, L., Harzhauser, M., Nagymrosy, A., Oszczypko, N., Pavelić, D., Rögl, F., Saftić, B., Sliva, L., Studencka, B., 2007. Badenian evolution of the Central Paratethys Sea: Paleogeography, climate and eustatic sea-level changes. Geologica Carpathica, 58: 579-606.

Köster, J., Kotarba, M., Lafargue, E., Kosakowski, P., 1998. Source rock and hydrocarbon potential of Oligocene Menilite Formation (Flysch Carpathians, Southeast Poland): an organic geochemical and isotope approach. Organic Geochemistry, 29: 543-558.

Krhovský, J., 1981a. Stratigraphy and paleoecology of the Menilitic Formation of the Ždánice Unit and the Diatomites of the Pouzdrany Unit (the Western Carpathians, Czechoslovakia). Zemní Plyn Nafta, 26: 45-62. 
Krhovský, J., 1981b. Microbiostratigraphic correlations in the Outer Flysch Units of the southern Moravia and influence of the eustasy on their palaeogeographical development. Zemní Plyn a Nafta, 26: 665-688.

Krzyżanowski, M., 1962. Previuos results of study on utility of the diagenetic diatomaceous slates (diatomites) from Leszczawka, near Przemyśl (in Polish with English summary). Przegląd Geologiczny, 10: 150-155.

Książkiewicz, M., 1972. Budowa geologiczna Polski, IV Tektonika, cz. 3. Karpaty (in Polish): 188-190. Wyd. Geol., Warszawa.

Książkiewicz, M., 1975. Bathymetry of the Carpathian Flysch Basin. Acta Geologica Polonica, 25: 309-368.

Kucharič, L., Bezák., V., Kubeš, P., Konečný, V., Vozár, J., 2013. New observed magnetic anomalies in the NE Slovakia Flysch belt (subvolcanic bodies?) and the Carpathian Conductivity Anomaly. Geological Quarterly, 57 (1): 123-134.

Leithold, E.L., Bourgeois, J., 1984. Characteristics of coarse-grained sequences deposited in nearshore, wave-dominated environments-examples from the Miocene of south-west Oregon. Sedimentology, 31: 749-775.

Leszczyński, S., Uchman, A., 1991. To the origin of variegated shales from flysch of the Polish Carpathians. Geologica Carpathica, 42: 279-289.

Lewan, M.D., Kotarba, M.J., Curtis, J.B., Więcław, D., Kosakowski, P., 2006. Oil generation kinetics for organic facies with Type-II and - IIS kerogen in Menilite Sahles of the Polish Carphatians. Geochimica et Cosmochimica Acta, 70 3351-3368.

Lexa, J. Bezák, M., Elečko, J., Mello, J., Polák, M., Poftaj, M., Vozár, J., Schnabel, G.W., Pálenský, P., Császár, G., Ryłko, W., Mackiv, B., 2000. Geologická mapa Západných Karpát a pril'ahlých území 1:500 000 (in Slovak). Geologická služba SR, Bratislava.

Linzer, H.-G., Frisch, W., Zweigel, P., Girbacea, R., Hann, H.-P., Moser, F., 1998. Kinematic evolution of the Romanian Carpathians. Tectonophysics, 297: 133-156.

Mahel', M., 1974. The Inner Carpathians. In: Tectonics of the Carpathian-Balkan Regions (ed. M. Mahel'): 91-133. GUDŠ, Bratislava.

Mahel', M., Buday, T., 1968. Regional Geology of Czechoslovakia The West Carpathians. Academia, Praha.

Maier, D., 1959. Systematik, Stratigraphie und Ökologie der Coccolithophorideen, Dinoflagellaten und Hystrichosphaerideen vom Oligozän bis Pleistozän. Neues Jahrbuch für Geologie und Paläontologie, 107: 278-340.

Majcin, D., Bilčik, D., Kutas, R., Hlavňová, P., Bezák, V., Kucharič, L., 2014. Regional and local phenomena influencing the thermal state in the Flysch belt of the northeastern part of Slovakia. Contributions to Geophysics and Geodesy, 44: 271-292.

Marshall, J.E.A., 1990. Determination of thermal maturity. In: Palaeobiology - A Synthesis (eds. D.E.G. Briggs and P. Crowther): 511-515. Blackwell Scientific Publications, Oxford.

Mayer, J., Sachsenhofer, R.F., Ungureanu, C., Bechtel, A., Gratzer, R., Sweda, M., Tari, G., 2018. Petroleum chargé and migration in the Black Sea: insights from oil and source rock geochemistry. Journal of Petroleum Geology, 41: 337-350.

McArthur, A.D., Kneller, B.C., Souza, P.A., Kuchle, J., 2016. Characterization of deep-marine channel-levee complex architecture with palynofacies: an outcrop example from the Rosario Formation, Baja California, Mexico. Marine and Petroleum Geology, 73: 157-173.

Melinte, M.C., 2005. Oligocene palaeoenvironmental changes in the Romanian Carpathians, revealed by calcareous nannofossils. Studia Geologica Polonica, 124: 341-352.

Mendonça Filho, J.G., Menezes, T.R., Oliveira Mendonça, J., Oliveira, A.D., Silva, T.F., Rondon, N.F., Silva, F.S., 2012. Organic facies: palynofacies and organic geochemistry approaches. In: Geochemistry - Earth's System Processes (ed. D. Panagiotaras): 211-248. InTech, Rijeka.
Metzger, P., Largeau, C., 2006. Botryococcus braunii: a rich source for hydrocarbons and related ether lipids. Applied Microbiology and Biotechnology, 66: 486-496.

Meyers, P.A., 1997. Organic geochemical proxies of paleoceanographic, paleolimnologic and paleoclimatic processes. Organic Geochemistry, 27: 213-250.

Miclauş, C., Loiacono, F., Puglisi, D., Baciu, D.S., 2008. Eocene-Oligocene depositional systems in the northern cratonic margin of the Paratethys: a study case from the Vrancea Nappe (Eastern Carpathians, Romania). Bulletin of the Tethys Geological Society, 3: 81-90.

Miclăuş, C., Loiacono, F., Puglisi, D., Baciu, D., 2009. Eocene-Oligocene sedimentation in the external areas of the Moldavide Basin (Marginal Folds Nappe, Eastern Carpathians, Romania): sedimentological, paleontological and petrographic approaches. Geologica Carpathica, 60: 397-417.

Mudie, P.J., 1992. Circum-Arctic Quaternary and Neogene marine palynofloras: paleoecology and statistical analysis. In: Neogene and Quaternary Dinoflagellate Cysts and Acritarchs (eds. M. J. Head and J. W. Wrenn): 347-390. American Association of Stratigraphic Palynologists Foundation, Dallas.

Mulder, T., Razin, P., Faugeres, J.C., 2009. Hummocky cross-stratification-like structures in deep sea turbidites: Upper Cretaceous Basque basins (Western Pyrenees, France). Sedimentology, 56: 997-1015.

Murgeanu, G., Dumitrescu, I., Mirauta, O., Sandalescu, M., Stefansecu, M., Bandrabur, T., 1970. Geological Map of Romania 1:200 000. Geological Institute of Romania, Bacau.

Murray, J.W., Jannasch, H.W., Honjo, S., Anderson, R.F., Reeburgh, W.S., Top, Z., Friedrich, L.A., Izdar, E., 1989. Unexpected changes in the oxic/anoxic interface in the Black Sea. Nature, 338: 411-413.

Myrow, P.M., Fischer, W., Goodge, J.W., 2002. Wave-modified turbidites: combined flow shoreline and shelf deposits, Cambrian, Antarctica. Journal of Sedimentary Research, 72: 641-656.

Nowak, W., 1965. Sur l'origine organique des calcaires de Jasło des couches ménilitique et de Krosno dans les Karpates flyscheuses (Oligocene). In: Carpatho-Balkan Geological Association, 7th Congress, Sofia, September 1965, Reports 2 (1) (eds. M. Ganev, J. Tencov, H. Spassov, H. Hrischev and S. Černjavska): 287-290. Bulgarian Academy of Sciences, Sofia.

Olaru, L., 1970. Recherches palynologique dans la Paléogène du flysch externe de la Vallée de la Bistriţa (Piatra Neamţ - Romania). Analele Ştiinţifice ale Universităţii „Al. I. Cuza” din Iaşi Seria Geologie, 16: 127-153.

Olszewska, B., 1982. Some remarks on biostratigraphy of the Menilite-Krosno series in the Polish Outer Carpathians (in Polish with English summary). Geological Quarterly, 26 (1): 137-145.

Olszewska, B., 1985. Foraminifera of the Menilite Beds (Polish External Carpathians) (in Polish with English summary). Annales Societatis Geologorum Poloniae, 55: 201-250.

Olszewska, B., Szydło, A., 2017. Environmental stress in the northern Tethys during the Paleogene: a review of foraminiferal and geochemical records from the Polish Outer Carpathians. Geological Quarterly, 61 (3): 682-695.

Oszczypko, N., Oszczypko-Clowes, M., 2003. The Aquitanian marine deposits in the basement of Polish Western Carpathians and its paleogeographical and paleotectonic implications. Acta Geologica Polonica, 53: 101-122.

Oszczypko, N., Ślączka, A., Oszczypko-Clowes, M., Olszewska, B., 2015. Where was the Magura Ocean? Acta Geologica Polonica, 65: 319-344.

Oszczypko-Clowes, M., Wójcik-Tabol, P., Płoszaj, M., 2015. Source areas of the Grybów sub-basin: micropaleontological, mineralogical and geochemical provenance analysis (Outer Western Carpathians, Poland). Geologica Carpathica, 66: 515-534. 
Paucă, M., 1931. Die fossile fauna und flora aus dem Oligozän von Suslanesti-Muscel in Rumänien (in Romanian with French summary). Anuarul Instiutului Geologic al României, 16: 577-663.

Paucă, M., 1936. Contributions à la connaissance des conditions de la sedimentation du flysch. Bulletin de la Section Scientifique Académie Roumaine, 18: 1-9.

Pilskaln, C. H., 1991. Biogenic aggregate sedimentation in the Black Sea. In: Black Sea Oceanography (eds. E. Izdar and J. Murray): 293-306. Kluwer Academic Publisher.

Plašienka, D., Grecula, P., Putiš, M., Kovác, M., Hovorka, D. 1997. Evolution and structure of the Western Carpathians: an overview. In: Mineralia Slovaca - Monograph (eds. P. Grecula D. Hovorka and M. Putiš): 1-24. Geological Survey of Slovak Republic, Bratislava.

Plint, A.G., Norris, B., 1991. Anatomy of ramp margin sequence facies successions, paleogeography, and sediment dispersa patterns in the Muskiki and Marshybank formations, Alberta Foreland Basin. Canadian Petroleum Geology Bulletin, 39: 18-42.

Pomar, L., Morsilli, M., Hallock, P., Badenas, B., 2012. Internal waves, an under-explored source of turbulent events in the sedimentary record. Earth-Science Reviews, 111: 56-81.

Popescu, B.M., Anastasiu, N., 2017. An overview of unconventional resources of Romania. Pending challenges. In: Shale GAS: Ecology, Politics, Economy (ed. S. S. Zhiltsov): 97-140 Springer International Publishing, Switzerland.

Popov, S.V., Studencka, B., 2015. Brackish-water Solenovian molluscs from the Lower Oligocene of the Polish Carpathians. Paleontological Journal, 49: 342-355.

Popov, S.V., Voronina, A.A., Gontscharova, I.A., 1993. Stratigraphy and Bivalves of the Oligocene-Lower Miocene of the Eastern Paratethys (in Russian). Publications of the Paleontological Institute, Russian Academy of Sciences, Moscow.

Popov, S.V., Antipov, M.P., Zastrozhnov, A.S., Kurina, E.E., Pinchuk, T.N., 2010. Sea-level fluctuations on the northern shelf of the Eastern Paratethys in the Oligocene-Neogene. Stratigraphy and Geological Correlation, 18: 200-224

Prekopová, M., Janočko, J., 2009. Quantitative approach in environmental interpretations of deep-marine sediments (Dukla Unit, Western Carpathian Flysch Zone). Geologica Carpathica 60: 485-494.

Pszonka, J., Wendorff, M., 2017. Carbonate cements and grains in submarine fan sandstones - the Cergowa Beds (Oligocene Carpathians of Poland) recorded by cathodoluminescence. International Journal of Earth Sciences, 106: 269-282.

Puglisi, D., Badescu, D., Carbone, S., Corso, S., Roberto, F. Gigliuto, L.G., Loiacono, F., Miclăuş, C., Moretti, E., 2006 Stratigraphy, petrography and palaeographic significance of the Early Oligocene „menilite facies” of Tarcău Nappe (Eastern Carpathians, Romania). Geologica Carpathica, 56: 485-494.

Rauball, J.F., Sachsenhofer, R.F., Bechtel, A., Coric, S., Gratzer, R., 2019. The Oligocene-Miocene Menilite Formation in the Ukrainian Carpathians: a world-class source rock. Journal of Petroleum Geology, 42: 393-416.

Roncaglia, L., 2004. Palynofacies analysis and organic-walled dinoflagellate cysts as indicators of paleo-hydrographic changes: an example from Holocene sediments in Skálafjord, Faroe Islands. Marine Micropaleontology, 50: 21-42.

Royden, L.H., Baldi, T., 1988. Early Cenozoic tectonics and palaeogeography of the Pannonian and surrounding region. AAPG Memoir, 45: 27-48.

Rögl, F., 1998. Palaeogeographic consideration for Mediterranean and Paratethys seaways (Oligocene to Miocene). Annalen des Naturhistorischen Museums in Wien, 99A: 279-310.

Rusu, A., 1999. Rupelian mollusc fauna of Solenovian type found in Eastern Carpathians (Romania). Acta Palaeontologica Romaniae, 2: 449-452.

Sachsenhofer, R.F., Hentschke, J., Bechtel, A., Coric, S., Gratzer, R., Gross, D., Horsfield, B., Rachetti, A., Soliman A., 2015. Hydrocarbon potential and depositional environments of Oligo-Miocene rocks in the Eastern Carpathians (Vrancea
Nappe, Romania). Marine and Petroleum Geology, 68: 269-290.

Săndulescu, M., 1975. Essai de synthése structurale des Carpathes. Bulletin de la Société Géologique de France, 17: 299-358.

Săndulescu, M., 1980. Analyse géotectonique des châines alpines situées autour de la mer Noir occidentale. Anuarul Institutului de Geologie şi Geofizică Romaniei, 56: 5-54.

Schnyder, J., Stetten, E., Baudin, F., Pruski, A.M., Martinez, P., 2017. Palynofacies reveal fresh terrestrial organic matter inputs in the terminal lobes of the Congo deep-sea fan. Deep Sea Research Part II: Topical Studies in Oceanography, 142: 91-108.

Shepard, F.P., 1964. Sea-floor valleys of Gulf of California. AAPG Memoir, 3: 157-192.

Sikora, W., Wieser, T., Żgiet, J., Żytko, K., 1959. Tuff horizons in the Menilite-Krosno Series of the Flysch Carpathians. Bulletin de L'Academie Polonaise des Sciences, Série des Sciences Géologiques et Géographiques, 7: 497-503.

Soták, J., 1998. Central Carpathian Paleogene and its constrains replay to Gross \& Filo' and Potfaj's comments. Slovak Geological Magazine, 4: 203-211.

Spicer, R.A., 1980. The importance of depositional sorting to the biostratigraphy of plant megafossils. In: Biostratigraphy of fossil plants (D. L. Dilcher and T. N. Taylor): 171-183. Dowdon, Hutchinson and Ross, New York.

Spicer, R.A., 1991. Plant taphonomic processes. In: Taphonomy: releasing the data locked in the fossil record: topics in geobiology (eds. P.A. Allison and D. Briggs), 9: 71-113.

Stefanescu, M., Dicea, O., Butac, A., Ciulavu, D., 2006. Hydrocarbon geology of the Romanian Carpathians, their foreland, and the Transylvanian Basin. AAPG Memoir, 84: 521-567.

Stránik, Z., Hanzlikowá, E., 1963. Geologická studie smilnenskoho okna. Sborník Ústředního Ústavu Geologického, 27: 456-495.

Studencka, B., Popov, S.V., Bieńkowska-Wasiluk, M., Wasiluk, R., 2016. Oligocene bivalve faunas from the Silesian Nappe, Polish Outer Carpathians: evidence of the early history of Paratethys. Geological Quarterly, 60 (2): 317-340.

Szajnocha, W., 1920. W sprawie łupków bitumicznych w Galicji (in Polish). Czasopismo Naftowe, Rok. I, 9: 83-84.

Ślączka, A., Krugłov, S., Golonka, J., Oszczypko, N., Popadyuk, I., 2006. Geology and hydrocarbon resources of the Outer Carpathians, Poland, Slovakia, and Ukraine: General geology. AAPG Memoir, 84: 221-258

Ślączka, A., Renda, P., Cieszkowski, M., Golonka, J., Nigro, F., 2012. Sedimentary basins evolution and olistoliths formation The case of Carpathian and Sicilian regions. Tectonophysics, 568-569: 306-319.

Śliwińska, K.K., Abrahamsen, N., Beyer, C., Brünings-Hansen, T., Thomsen, E., Ulleberg, K., Heilmann-Clausen, C., 2012. Bio- and magnetostratigraphy of Rupelian-mid Chattian deposits from the Danish land area. Review of Palaeobotany and Palynology, 172: 48-69.

Tabără, D., 2010. Palynology, palynofacies and thermal maturation of the kerogen from the Moldavidian Domain (Gura Humorulu Area). Analele Ştiinţifice Ale Universităţii „Al. I. Cuza” Iaşi Geologi, 56: 53-73

Tabără, D., 2017. Dinoflagellate cysts stratigraphy and palynofacies of Oligocene sequences in the Northern Eastern Carpathians. Acta Palaeontologica Romaniae, 13: 49-63.

Tabără, D., Pacton, M., Makou, M., Chirilă, G., 2015. Palynofacies and geochemical analysis of OligoMiocene bituminous rocks from the Moldavidian Domain (Eastern Carpathians, Romania): Implications for petroleum exploration. Review of Palaeobotany and Palynology, 216: 101-122.

Tinterri, R., Muzzi Magalhaes, P., 2011. Synsedimentary structural control on foredeep turbidites: an example from Marnosoarenacea Formation, Northern Apennines, Italy. Marine and Petroleum Geology, 28: 629-657.

Tyson, R.V., 1989. Late Jurassic palynofacies trends, Piper and Kimmeridge Clay formations, UK onshore and Northern North Sea. In: Northwest European Micropalaentology and Palinology 
(D.J. Batten and M.C. Keen): 135-172. British Micropaleontological Society Series. Ellis Horwood, Chichester.

Tyson, R.V., 1993. Palynofacies analysis. In: Applied Micropaleontology (ed. D.J. Jenkins): 152-191. Kluwer Academic Publishers, Dordrecht.

Tyson, R.V., 1995. Sedimentary Organic Matter: Organic Facies and Palynofacies. Chapman and Hall, Torquay, Devon.

Tyson, R.V., Wilson, R.C.L., Downie, C., 1979. A stratified water column environmental model for the type Kimmeridge Clay. Nature, 277: 377-380.

Uhlig, V., 1882. Reisebericht aus Westgalizien: Funde cretazischer und alttertiärer Versteinerungen. Verhandlungen der Geologischen Reichensalt, 15-16: 306-307.

Unrug, R., 1979. Palinspastic reconstruction of the Carpathian arc before the Neogene tectogenesis. Rocznik Polskiego Towarzystwa Geologicznego, 49: 3-21.

Uroza, C.A., Steel, R.J., 2008. A highstand shelf-margin delta system from the Eocene of West Spitsbergen, Norway. Sedimentary Geology, 203: 229-245.

Van Couvering, J.A., Aubry, M.P., Berggren, W.A., Bujak, C.W., Naeser, C.W., Wieser, T., 1981. The terminal Eocene event and the Polish connection. Palaeogeography, Palaeoclimatology, Palaeoecology, 36: 321-362.

Van Gijzel, P., 1961. Autofluorescence and age of some fossil polIen and spores. Proceedings of the Koninklijke Nederlandse Akademie van Wetenschappen. Series B: 56-63.

Vetö, I., 1987. An Oligocene sink for organic carbon: upwelling in the Parathetys? Palaeogeography, Palaeoclimatology, Palaeoecology, 60: 143-153.

Vetö, I., Hetényi, M., 1991. Fate of organic carbon and reduced sulphur in dysoxic-anoxic Oligocene facies of the Central Paratethys (Carpathian Mountains and Hungary). Geological Society Special Publications, 58: 449-460.

Vigran, J.O., Mørk, A., Forsberg, A.W., Weiss, H.M., Weitschat, W., 2008. Tasmanites algae - contributors to the Middle Triassic hydrocarbon source rocks of Svalbard and the Barents Shelf. Polar Research, 27: 360-371.

Voronina, A.A., Popov, S.V., 1984. Solenovian horizon from Eastern Paratethys (in Russian). Bulletin of the Academy of Sciences of the USSR, ser. Geology, 9: 41-53.

Wagner, R., ed., 2008. Tabela stratygraficzna Polski - Karpaty (in Polish). Państwowy Instytut Geologiczny, Warszawa.

Waples, D., 1985. Geochemistry in Petroleum Exploration. Boston. International Human Resources Development Corp., Boston.

Watkinson, M.P., Enfield, M.A., Seymour, M.D., 2001. Predicting turbidite reservoir presence and quality in the Polish Carpathians. Application of sequence stratigraphy in exploration. In: Carpathian Petroleum Conference. Application of Modern Exploration Methods in a Complex Petroleum Systems. Wysowa, June 2001 (ed. P. Dziadzio): 8-10.

Wendorff, M., Rospondek, M. J., Kluska, B., Marynowski, L., 2017. Organic matter maturity and hydrocarbon potential of the Lower Menilite facies in the Eastern Flysch Carpathians (Tarcău and Vrancea Nappes), Romania. Applied Geochemistry, 78: 295-310.

Więcław, D., Kotarba, M.J., Kowalski, A., Kosakowski, P., 2011 Habitat and hydrocarbon potential of the Palaeozoic source rocks in the Kraków-Rzeszów area (SE Poland). Annales Societatis Geologorum Poloniae, 81: 375-394.

Więcław, D., Kotarba, M.J., Kowalski, A., Koltun, Y.V., 2012. Origin and maturity of oils in the Ukrainian Carpathians and their Mesozoic basement. Geological Quarterly, 56 (1): 153-168.

Williams, G.L., Lentin, G.P., Fensome, R.A., 1998. The Lantin and Willimas Index of Fossil Dinofalegllates, 1998. American Association of Stratigraphic Palynologists Foundation., Dallas, TX, 29-50.

Ziegler, P.A., Roure, F., 1999. Petroleum system of Alpine-Mediterranean foldbelts and basin. Geological Society Special Publications, 156: 517-540.

Zuber, R. 1918. Flisz i nafta (in Polish). Towarzystwo dla Popierania Nauki Polskiej, Lwów. 